【委員会報告】

\title{
救急外来部門における感染対策チェックリスト
}

\author{
佐々木 淳一 ${ }^{1,}$ a, 椎野 泰和 ${ }^{2}$, 加藤 康幸 ${ }^{3}$, 工藤 大介 ${ }^{4}$, 藤田 昌久 ${ }^{5}$, \\ 宮入 烈 6 , 望月 徹 ${ }^{7}$, 奥田 拓史 ${ }^{8}$, 長門 直 ${ }^{9}$, 鍋谷 佳子 ${ }^{10}$, 高橋 毅 ${ }^{11}$, \\ 救急外来部門における感染対策検討委員会 12 および合同ワーキンググループ 13,14,15,16

\section{Checklist for infection control in the emergency department} \\ Junichi Sasaki ${ }^{1}$, Yasukazu Shiino ${ }^{2}$, Yasuyuki Kato ${ }^{3}$, Daisuke Kudo ${ }^{4}$, Masahisa Fujita ${ }^{5}$, \\ Isao Miyairi ${ }^{6}$, Touru Mochizuki ${ }^{7}$, Hiroshi Okuda ${ }^{8}$, Tadashi Nagato ${ }^{9}$, Yoshiko Nabetani ${ }^{10}$, Takeshi Takahashi ${ }^{11}$, \\ and on behalf of Committee for Infection Control in the Emergency Department ${ }^{12}$ and the Joint Working Group ${ }^{13,14,15,16}$
}

1 慶應義塾大学医学部救急医学

Department of Emergency and Critical Care Medicine, Keio University School of Medicine

2 川崎医科大学救急医学

Department of Acute Medicine, Kawasaki Medical School

3 国際医療福祉大学医学部感染症学

Department of Infectious Diseases, International University of Health and Welfare School of Medicine

4 東北大学大学院医学系研究科外科病態学講座救急医学分野

Division of Emergency and Critical Care Medicine, Tohoku University Graduate School of Medicine

5 日本医科大学付属病院医療安全管理部感染制御室

Infection Control Team, Nippon Medical School Hospital

6 国立成育医療研究センター生体防御系内科部感染症科

Division of Infectious Diseases, National Center for Child Health and Development

7 日本医科大学武蔵小杉病院感染制御部/救命救急科（救命救急センター）

Infection Control Team, Nippon Medical School Musashi Kosugi Hospital

8 東北大学大学院医学系研究科総合医療学分野

Division of Comprehensive Medicine, Tohoku University Graduate School of Medicine

9 公立学校共済組合中国中央病院内科

Department of Internal Medicine, Chugoku Central Hospital

10 大阪大学医学部附属病院看護部

Division of Nursing, Osaka University Hospital

${ }^{11}$ 国立病院機構熊本医療センター

National Hospital Organization Kumamoto Medical Center

12 一般社団法人 日本救急医学会

Japanese Association for Acute Medicine

13 一般社団法人日本環境感染学会

Japanese Society for Infection Prevention and Control

14 一般社団法人 日本感染症学会

Japanese Association for Infectious Diseases

15 一般社団法人日本臨床救急医学会

Japanese Society for Emergency Medicine

16 一般社団法人 日本臨床微生物学会

Japanese Society for Clinical Microbiology

a 个160-8582 東京都新宿区信濃町 35

原稿受理日：2019年 12 月 25 日 (JJAAM-2019-0108) 
要旨 救急外来部門では, 新興感染症も含め, 様々なヒト - ヒト感染症と遭遇する危険性があり, その感染 対策は十分かつ適切に行われるべきである。しかし，救急外来部門での感染対策について十分なエビデンス に基づいて作成されたガイドラインなどはこれまで世界的にも作成されておらず，各施設で独自の対応策を 検討・実施している。日本救急医学会は「救急外来部門における感染対策検討委員会」を設置し，日本感染 症学会, 日本環境感染学会, 日本臨床救急医学会, 日本臨床微生物学会とともに 5 学会連携の救急外来部門に おける感染対策について検討する合同ワーキンググループを組織した。この合同ワーキンググループにおい て，救急外来における感染対策およびそれに関連する事項について総合的かつ多面的に検討を行い，「救急 外来部門における感染対策チェックリスト」を公開するに至った。本チェックリストは，救急専従医が少数 あるいは配置されていない小規模な救急外来部門であっても，このチェックリストに従い準備をすれば大き な間違いをせずに感染対策が行えることを目的に作成された。この中には，感染対策の管理体制，教育・検 診・予防接種体制，感染が疑われる患者への対応，ハード面の感染リスク管理などが含まれており，さらに チェックすべき時期やその間隔については，それぞれカテゴリーとして明示している。本チェックリスト が，救急外来部門における感染対策の充実に資することを期待したい。

(日救急医会誌. 2020; 31: 73-111)

キーワード : 救急室, 感染防止, 職業感染, ワクチン接種, 環境改善

The risk of encountering a variety of human-to-human infections, including emerging infectious diseases, should be adequately and appropriately addressed in the emergency department. However, no guidelines have been developed anywhere in the world based on sufficient evidence on infection control in the emergency department. Each facility examines and implements its own countermeasures. The Japanese Association for Acute Medicine has established the "Committee for Infection Control in the Emergency Department" in cooperation with the Japanese Association for Infectious Diseases, the Japanese Society for Infection Prevention and Control, the Japanese Society for Emergency Medicine, and the Japanese Society for Clinical Microbiology. A joint working group has been established to consider appropriate measures. This group conducted a comprehensive and multifaceted review of infection control measures for emergency outpatients and related matters, and released a Checklist for Infection Control in Emergency Departments. This checklist has been prepared so that even small emergency departments with few or no emergency doctors can control infection by following the checklist, without committing any major mistakes. The checklist includes a control system for infection control, education, screening, and vaccination, promptly responding to suspected infections, and managing the risk of infection in facilities. In addition, the timing of the check and the interval at which the check is performed are specified as categories. We hope that this checklist will contribute to improving infection control in the emergency department.

(JJAAM. 2020; 31: 73-111)

Keywords: emergency room (ER), infection prevention, occupational infection, vaccinations, environmental improvement Received on December 25, 2019 (JJAAM-2019-0108)

チェックリスト発行日 2019 年 12 月 20 日

\section{付 記}

・救急外来部門における感染対策検討委員会全メンバーの 氏名・所属・利益相反一覧表は巻末に示した。

・本チェックリストには，倫理委員会による審査の必要性 および個人情報保護法に関連する内容は含まれていな い。

\section{目次}

はじめに $\cdot 112$

日本救急医学会の取り組み 112 本チェックリストの概要 .113

1. 管理体制 ...113

(1) 組織 ....113
(2) 教育 ·検診 ·予防接種体制 ……………………………115

(1) 感染制御に関する管理・教育 …………………115

(2) 結核検診 ………………………………………………116

(3) ワクチン接種 ……………………………………….... 116

2. 感染が疑われる患者への対応 ………………………….... 118

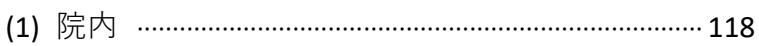

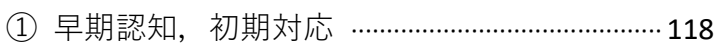

(2) 感染予防の具体策 …………………………………124

(3) 環境整備 …………………………………………….... 127

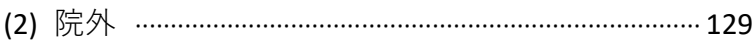

(4) 救急搬送……………………………………………1 129

(5) 病院間搬送 ………………………………………..... 135

3. モニタリング ………………………………………………..... 136

(1) 機器, 環境など ……………………………………….... 136

4. 構造, ハードウェアの感染リスクの管理 ……………137 
(1) トイレ 137

(2) 待合室 .. 137

(3) 診察区域 139

(4) 新規に採用される医療機器・医療材料 140

5. 多剂耐性菌の監視および対応

6. 新興 - 再興感染症対策

7. 行政との連携

項目一覧 144

略語一覧 146

\section{図の目次}

図 1 麻疹・風疹・流行性耳下腺炎・水痘ワクチン接 種のフローチャート

図 2 感染症問診票例

119

図 3 掲示文例 120

図 4 感染スクリーニング例 122

図 5 感染スクリーニング体制の強化 $\cdot 122$

\section{表の目次}

表 1 曝露後の対処

表 2 SPAULDING の分類

.129

表 3 職業感染対策

$\cdot 131$

表 4 滅菌，消毒，洗浄の定義と対象資器材 …………13..132

表 5 感染症法上の分類と消毒方法

.133

\section{救急外来部門における感染対策検討委員会}

および合同ワーキンググループ 委員一覧 148

\section{救急外来部門における感染対策検討委員会}

全メンバーの氏名・所属・利益相反一覧表

はじめに

救急外来部門では，新興感染症も含め，様々な ヒトーヒト感染症と遭遇する危険性があり，その感 染対策は十分かつ適切に行われるべきである。し かし, 救急外来診療には迅速性が求められる一方 で，患者や家族からの情報収集の難しさや複雑さ などから診断が進まない場合も多く，感染対策発 動の遅れという危険性が高い。その解決策は, 救 急外来部門の医療従事者（傷病者を搬送してくる 救急隊員も含め）の職業感染対策を充実させるこ とといえる。しかし, 救急外来部門での感染対策
について十分なエビデンスに基づいて作成された ガイドラインやマニュアルはこれまで世界的にも 作成されておらず，全国の救急外来部門で診療に 従事する者は多くの不安を抱えながらも，旧来の 経験的手順書や，行政よりの通達を頼りとして， 各施設で独自の対応策を検討・実施している現実 がある。一方で, 救急外来部門の運営体制は, 施 設間格差が大きく, 科学的根拠のある項目を強く 推奨することにより，それぞれの施設・医療者に とって大きな負担を強いることも望ましくない。 このような現状を鑑みると, 救急外来部門におけ る感染対策を考えていくには，救急医療の視点の みならず感染対策（制御）よりの視点も踏まえた 総合的な検討が必要であると考えられる。

日本救急医学会の取り組み

2015 年 1 月, 日本救急医学会「救急外来部門に おける感染対策検討委員会」が設置され，日本感 染症学会, 日本環境感染学会, 日本臨床救急医学 会, 日本臨床微生物学会とともに 5 学会連携の救急 外来部門における感染対策について検討する「合同 ワーキンググループ（以下，合同 WG）」が組織さ れた。この合同 WG では，専門的学術団体の立場 で，救急外来における感染対策およびそれに関連 する事項について総合的かつ多面的に検討が行わ れた。その第一段階として，アンケート形式による 3 つの現状調査, 日本救急医学会専門医認定施設を 対象にした救急外来部門における感染対策につい ての調査 ${ }^{1)}$ ，全国消防機関を対象にした病院前救護 活動での感染対策についての調査 ${ }^{21}$, 日本臨床微生 物学会認定臨床微生物検査技師登録者施設を対象 にした救急外来部門における微生物検査体制につ いての調査 ${ }^{3)}$ を行った。次に第二段階として, こ れらの調査結果に基づく救急外来の特殊性を考慮 に入れた感染対策を学会として社会に発信してい くことになり，この度「救急外来部門における感 染対策チェックリスト」を公開するに至った。 


\section{本チェックリストの概要}

「救急外来部門における感染対策チェックリス ト」は，救急部門の専従医が少数あるいは配置され ていないような小規模な救急外来部門であっても， 本チェックリストに従い準備を行うことにより大き な間違いをせずに感染対策が行えることを目的に作 成された。この中には，感染対策の管理体制，教 育・検診・予防接種体制, 感染が疑われる患者への 対応，ハード面の感染リスク管理などが含まれてお り，さらにチェックすべき時期やその間隔について は全ての項目が一様ではないことを前提にして，そ れぞれカテゴリーとして明示した。

<カテゴリー>

・年 1 回：ハード面の確認や管理体制のチェック が中心

- 四半期 (常時)：いわゆる手順などのソフト面の 確認が中心

- 特定：新規採用者や物品の導入, 感染症の流行 状況を考慮した情報のアップデートを目的とし た項目

・臨時：パンデミック, 新興感染症に対する対応 が中心

また，結核に関連した項目については，日本結 核・非結核性抗酸菌症学会（日本結核病学会上り改 称）藤田明理事長に協力を頂いた。

本チェックリストは，日本救急医学会雑誌に掲載 された後, 5 学会合同ワーキングの構成学会である 日本環境感染学会・日本感染症学会・日本臨床救急 医学会・日本臨床微生物学会の各機関誌にも掲載さ れる。

著者の佐々木淳一は, アステラス製薬株式会社, MSD 株式会社，大日本住友製薬株式会社，ファイ ザー株式会社より講演料，ロシュ・ダイアグノス ティックス株式会社より研究費，アステラス製薬株 式会社, ファイザー株式会社より奨学寄付金を受け た。合同ワーキンググループ委員の志馬伸朗は, MSD 株式会社，株式会社大塚製薬工場，第一三共
株式会社，大日本住友製薬株式会社，ファイザー株 式会社より講演料，旭化成ファーマ株式会社，塩野 義製薬株式会社，ファイザー株式会社より奨学寄付 金を受けた。柳原克紀は，アステラス製薬株式会 社，MSD 株式会社，大正富山医薬品株式会社，第 一三共株式会社，日本ベクトン・ディッキンソン株 式会社，ファイザー株式会社，ビオメリュー・ジャ パン株式会社より講演料，杏林製薬株式会社，塩野 義製薬株式会社，日本ベクトン・ディッキンソン株 式会社より研究費，MSD 株式会社，第一三共株式 会社，大日本住友製薬株式会社，富山化学工業株式 会社，ファイザー株式会社，Meiji Seika ファルマ株 式会社より奨学寄付金を受けた。

その他の著者, 合同ワーキンググループ委員に 利益相反はない。

\section{1. 管理体制}

\section{(1) 組織}

\section{項目 1. 院内の感染対策委員会に救急外来の責任者 が含まれている。}

<カテゴリー>

年 1 回

$<$ 解説 $>$

救急外来は疾患, 重症度の多様な患者が受診し, 入院が必要な患者の病院における玄関ともなってい る。緊急時のデバイス挿入など侵襲的手技や感染症 患者の受診もまれではない。また，災害時や感染症 流行時には救急外来が受診者の空口になることを想 定している場合も多い。このため，救急外来は医療 関連感染が生じやすい部門と考えられるが，限られ た情報を基に診療が行われるため，感染リスクの評 価は十分に行えないことも多いと考えられる。実際 に2015 年の韓国における中東呼吸器症候群 (MERS) の流行では, 3 次医療機関の救急外来が感染伝播の 主要な場となった4)。

救急外来の医療従事者における感染対策の実践に 
加えて，病院全体が救急外来における感染対策の重 要性を認識し，取り組むことが重要である。医療関 連感染について情報を収集し，対策を決定する感染 対策委員会に救急外来の責任者（医師に限らず救急 外来に専従し実質の管理を行っているもの）が参加 することを考慮する5 5 。救急外来の特殊性について 他部門関係者の関心を高め, 救急外来の感染対策の 改善を図ることが期待できる。

項目 2. 新型インフルエンザなど新興・再興感染症 流行時などに設置される対策本部に，救急外来の責 任者が含まれている。

<カテゴリー>

臨時

<解説 >

救急外来は新型インフルエンザなど新興・再興感 染症流行時には受診者の空口になることが想定され る。実際に, 2003 年の重症急性呼吸器症候群 (SARS), 2009 年の新型インフルエンザ, 2015 年の 韓国における中東呼吸器症候群（MERS）の流行で は，救急外来に患者が多数受診し，医療関連感染の 発生も報告されている4)。救急外来から病棟に入院 する患者も生じるため, 救急外来の感染対策は病院 全体の課題でもある。また，地震などの災害時には 避難所でインフルエンザやウイルス性胃腸炎が流行 し，患者が救急外来を受診することなども予想され る。このような災害時にも感染対策が必要となるこ とがあり，救急外来が重要な役割を持つことを認識 する必要がある。

このような観点から，新型インフルエンザなど新 興・再興感染症流行時などに設置される対策本部に 救急外来の責任者（医師に限らず救急外来に專従し 実質の管理を行っているもの）が参加することが望 ましい6)。

\section{項目 3. 感染制御の専門家に必要時 24 時間相談でき る体制を整えている。}

<カテゴリー>
年 1 回

<解説 >

感染対策には，針刺し後の曝露後発症予防など緊 急を要する処置を行う場合が含まれる。また，新型 インフルエンザなど新興・再興感染症が流行した際 に救急外来の受診者が急増して，待合エリアを拡充 する必要に迫られることなども想定される。24 時 間診療を行っていることが多い救急外来では，この ようなことが夜間や休日に発生する場合も想定して おく必要がある。これらの事例が発生した際には, 緊急で感染リスクを評価するなどの専門的な判断や 専門家による手順の認証が必要となることが多い。 経験と知識を有する院内の感染制御の専門家（院内 の感染対策担当部門にかかわっている方，あるいは 院内の感染対策マニュアルに規定されている方） に，救急外来から必要時いつでも（夜間・休日は携 帯電話などを利用）相談できる体制を構築しておく ことが重要である7。

項目 4. 救急外来専用の感染対策マニュアルが整備 されている，あるいは感染対策マニュアルに救急外 来に関する事項が含まれ，定期的に見直し，改訂が 行われている。

<カテゴリー>

年 1 回

$<$ 解説 $>$

救急外来は疾患，重症度において多様な患者が受 診し，入院が必要な患者の病院における玄関とも なっている。緊急下でのデバイス挿入など侵襲的手 技やインフルエンザやウイルス性胃腸炎などの感染 症患者の受診もまれではない。災害時や新型インフ ルエンザなど新興・再興感染症流行時には救急外来 が受診者の空口になることを想定している場合も多 い。限られたスペースや時間で診療が行われている ことも多く, 救急外来は医療関連感染が生じやすい 部門と考えられる。このような救急外来の特殊性を 考慮した感染対策マニュアルが整備されていること が望ましい7)。2015 年に実施された日本救急医学会 
による専門医所属医療機関の調査では，救急外来に 関する感染対策マニュアルを有さない施設が 51 （16.8\%）あった 1$)$ 。救急外来専用の感染対策マニュ アルではなく，院内感染マニュアルに救急外来の項 目を設けるのでも構わない。定期的に見直し，改訂 が行われることが重要である。

\section{（2）教育・検診・予防接種体制}

\section{(1) 感染制御に関する管理・教育}

\section{項目 5. 常勤職員だけでなく，救急外来に関わる職} 員全員に対し，感染制御に関する研修を行っている。

<カテゴリー>

年 1 回

$<$ 解説 $>$

救急外来の運営に関与する職員には多様な職種 （狭義の医療従事者のほかに受付事務，清掃員，警 備員なども含まれる）が存在するが，常勤，非常勤 やフルタイム，パートタイムといった雇用形態を問 わず，すべての職員に感染リスクがあると想定し て，感染制御に関する研修が行われる必要がある7)。 緊急時においても感染対策を確実に実施できるよう にすることが目標である。中途採用者がある場合に は入職時に研修を行う必要がある。研修の内容は, 標準予防策［血液体液曝露を防ぐ個人防護具 （PPE）使用法を含む]，末梢静脈ラインの確保 ${ }^{8}$, 調剂・薬剂投与における感染制御などを職種に応じ て含めることが望ましい。受付から待合室までの動 線の確認，呼吸器症状（咳，インフルエンザ様症 状，気道分泌物増加など）のある患者への咳エチ ケットの励行などは受付事務職員にも重要な内容で ある。また，新型インフルエンザなど新興・再興感 染症流行時には，国による症例定義，疑い患者のト リアージ手順，個人防護具（PPE）の使用法などに ついて，臨時の研修を開催することが望ましい。

項目 6. N95 マスクの正しい着脱のトレーニングと, 定期的なフィットテストが実施されている。
<カテゴリー＞

年 1 回

$<$ 解説 $>$

フィットテスト（定量式が望ましい）は，自分に 合う N95 マスクのサイズ・形状，フィットする状 態，漏れのある状態を数值で確認することが可能と なり，職業曝露防止のための知識と技量を体得する ための方法の一つである。米国疾病予防管理セン

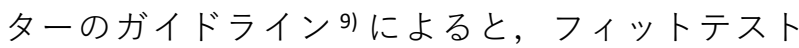
は，(1)医療従事者の安全のため，(2)正しい着脱方法 のトレーニングのため，(3)自身に合う N95 マスクを 確認するため, とされている。

N95 マスクのフィットテストの実施規定は日本で はないが，入職時や曝露リスクの高い部署に配属に なった時には実施する必要がある。米国労働安全衛 生局 ${ }^{10)}$ では，N95 マスクの導入時，その後は 1 回/ 年，それ以外でも体重の増減や顔貌の変化があった ときや着用者からの要望時に行うことが義務づけら れている。

項目 7. 新型インフルエンザなど新興・再興感染症 流行時には，症例定義，感染制御法などに関する情 報が速やかに周知される。

<カテゴリー＞

臨時

$<$ 解説 $>$

特定の感染症が流行した場合，速やかな情報共 有，対策が救急外来においては特に重要である。 「感染症の予防及び感染症の患者に対する医療に関 する法律」11)（感染症法）の「第七章，新型インフ ルエンザ等感染症」（新型インフルエンザ等感染症 の発生及び実施する措置等に関する情報の公表）に おいて，「第四十四条の二 厚生労働大臣は，新型 インフルエンザ等感染症が発生したと認めたとき は，速やかに，その旨及び発生した地域を公表する とともに，当該感染症について，第十六条の規定に よる情報の公表を行うほか，病原体であるウイルス の血清亜型及び検査方法, 症状，診断及び治療並び 
に感染の防止の方法，この法律の規定により実施す る措置，その他の当該感染症の発生の予防又はその まん延の防止に必要な情報を新聞，放送，インター ネットその他適切な方法により逐次公表しなければ ならない」とされている。対応の詳細ついては，内 閣官房所管法令「新型インフルエンザ等対策特別措 置法」に記載されている。 ( http://www.cas.go.jp/jp/ influenza/120511houritu.html)

また，感染症法における「指定感染症」やその他 高病原性鳥インフルエンザ等に係る「指定感染症」 に関連する対応については，有事の際の病院の業務 継続計画（BCP）にも影響するため，臨時であって も迅速に公的通知等に対応できるよう，情報収集と 共有・周知に関する院内ガバナンスの整備が重要で ある。

\section{(2) 結核検診}

\section{項目 8. 入職時及び最低年 1 回の結核に係る定期の 健康診断が実施されている。}

＜カテゴリー＞

年 1 回

<解説 >

結核の定期健康診断は感染症法第 53 条に規定さ

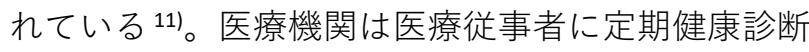
を行う事業者に指定されており，毎年度に 1 回健康 診断を行うことが義務づけられている。その対象者 にも受診の義務がある。健康診断は胸部 X 線検査が 中心となる。これに加えて，結核患者に接触した場 合には必要に応じて，接触者健診が行われる。健診 とは別に，咳嗽が 2 週間以上続く場合は医療従事者 においても，胸部 X 線検査などを行い結核の可能性 がないかについて確認する。

入職時にツベルクリン検査を行う医療機関が多 かったが，小児期の BCG 接種による影響性を受ける ため，近年はインターフェロン $\mathrm{v}$ 遊離試験（IGRA） を行うことが推奨されている。日本国内では，結核
病棟など恒常的に結核菌に曝露される環境で勤務す る職員には入職後にも定期的な検査が推奨される が ${ }^{12)}$ ，救急外来の職員に一律に実施するのは一般的 ではない。結核低まん延国である米国のガイドライ ンでは，結核患者を前年に 3 人以上診療した施設は 中等度のリスクと評価し，医療従事者に年 1 回のツ ベルクリン検査，あるいは IGRA を行うことを推奨 している ${ }^{13)}$ 。これによって，2 年以内の比較的早期 の感染を把握し，潜在性結核感染症の治療（予防内 服）につなげて職員の発症を防止することを目指し ている。

なお, 救急外来職員に対する入職時の BCG 接種 は推奨されない。

\section{(3) ワクチン接種}

項目 9. インフルエンザワクチンの接種が推奨され, 管理されている。

<カテゴリー>

年 1 回

$<$ 解説 $>$

インフルエンザは感染前にワクチンで予防するこ とが最も有効な防御手段とされている。インフルェ ンザワクチンの効果に関して，ワクチン株と流行株 とが一致している場合には，65 歳以下の健常成人 での発症予防効果は 70～90\%，施設内で生活してい る高齢者での発症予防効果は 30〜40\%と下がるが, 入院や肺炎を防止する効果は 50～60\%，死亡の予防 効果は 80\%みられたと報告されている ${ }^{14)}$

特にインフルエンザ患者と接触するリスクの高い 医療関係者においては，自身への職業感染防止の観 点，患者や他の職員への施設内感染防止の観点，お よびインフルエンザ罹患における欠勤防止のいずれ の観点からも，積極的にワクチン接種を受けること

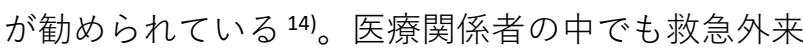
の職員は，よりインフルエンザ患者との接触のリス クが高く, 接種不適当者に該当しない救急外来の職 員は，全員がワクチン接種を受けることが強く推奨 


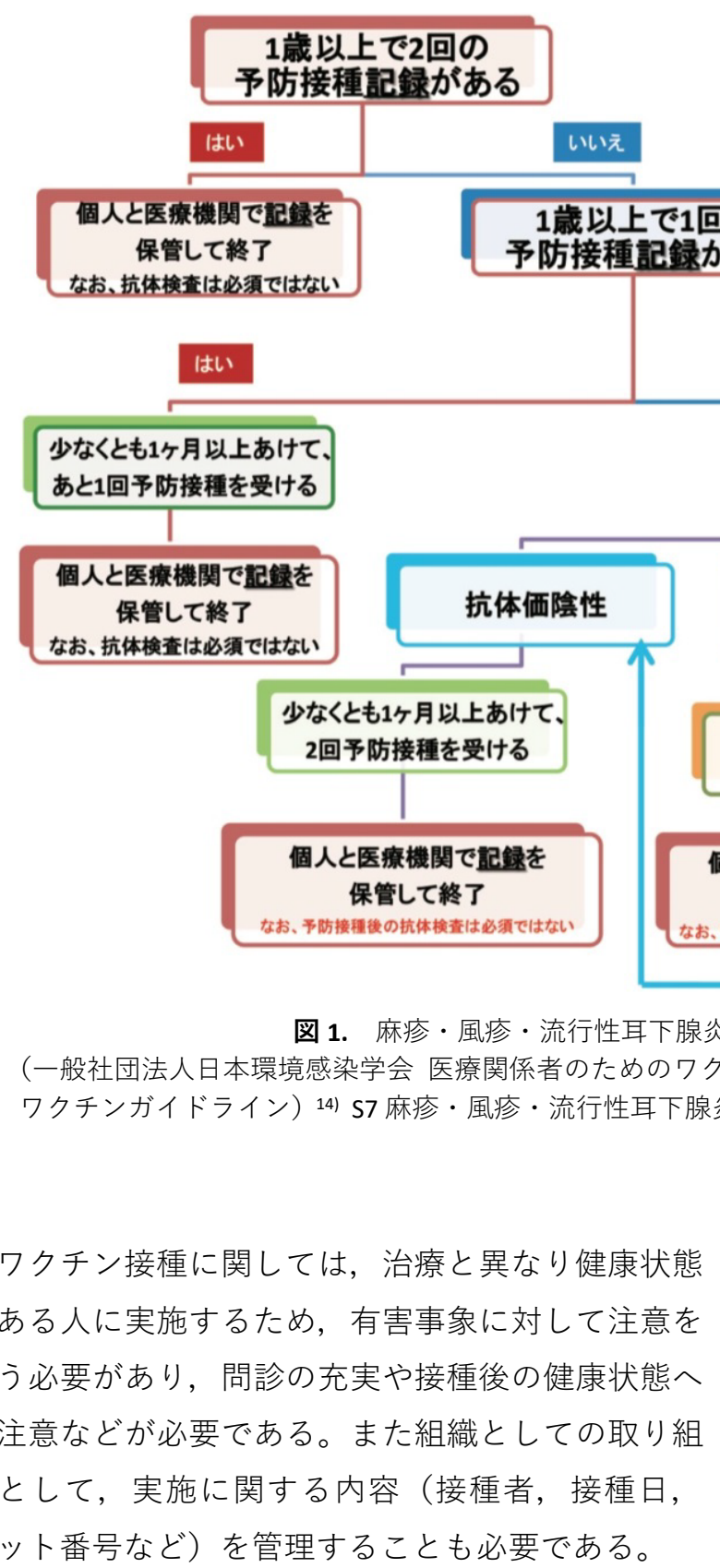

項目 10. 麻疹，水痘，風疹，ムンプス，HBV の免疫 （ワクチン接種回数，抗体価）が確認され管理され ている。

<カテゴリー>

特定

$<$ 解説 $>$

医療関係者が麻疹, 水痘, 風疹, ムンプスを発症 すると，本人の重症化の可能性に加え，周囲の患者
得しておくことが望ましいとされている ${ }^{15)}$ 。特に救 急外来には，急な発熱や発疹などの症状で受診する 患者もあり，罹患者と接触するリスクも高く，免疫 を獲得しておくことが強く推奨される。これらの 4 疾患はワクチン接種後に年数経過とともに免疫が減 衰することもあり, 複数回のワクチン接種（1 歳以 上で「2 回」を原則）が推奨されている。また、ワ クチンを接種しても免疫が獲得できない場合や，接 種不適当者の場合もあるため, 幼少時のワクチン接 種歴, 抗体価測定結果, 近年のワクチン接種歴など を管理しておくことが必要である。図 1 のフロー チャートに準じ，平常時から対応しておくことが, 罹患者と接触した場合の迅速な対応に繋がる ${ }^{14) 。}$

医療従事者は，患者の血液・体液に接する可能性 が高く，なかでも救急外来では観血的処置が多く, 
血液・体液に曝露するリスクが非常に高い。そのう え，患者の情報は得られない状態がほとんどであ り，血液媒介感染には注意が必要である。B 型肝炎 ウイルスは血液媒介感染をする病原体としては最も 感染力が強く，患者に使用した鋭利器材による針刺 しや切創, 血液・体液の粘膜への曝露などで感染が 成立する。患者の背景や提供される医療から, 救急 外来の医療従事者は B 型肝炎ワクチンを接種し，充 分な免疫獲得をしておくべきである。

\section{項目 11. 新型インフルエンザなど新興・再興感染症 流行時には, 行政機関と連携して臨時の予防接種が できる体制がある。}

<カテゴリー>

年 1 回及び臨時

$<$ 解説 $>$

医療施設は，新型インフルエンザ等対策特別措置 法の規定に基づく特定接種（医療分野）の対象とな り得る。特定接種を受けるには，事業者が特定接種 管理システムに登録する必要があり，登録には医療 提供事業であることや業務継続計画（BCP）を作成 していることが要件となる ${ }^{16) 。 ~}$

登録を受けた事業者は，新型インフルエンザ等の 発生時においても，医療の提供を継続的に実施する よう努めなければならない。よって事業者は施設内 のワクチンの接種対象者数を把握し，接種順位など を予め決定しておく必要がある。

救急外来は新型インフルエンザなど新興・再興 感染症の診療を最初に行う可能性が高く, 施設の 中でもワクチン接種の優先順位の高い部署であ る。救急外来のスタッフがワクチン接種の対象者 として，優先順位が高く設定されているかを確認 しておくべきである。

\section{2. 感染が疑われる患者への対応}

\section{(1) 院内}

(1) 早期認知，初期対応
項目 12. 患者から事前の電話連絡があった場合，あ るいは受付において，患者に最初に接触する職員が 感染症を認知する為に聴取する質問項目をチェック リスト形式で作成し，適宜アップデートしている。

<カテゴリー＞

四半期（常時）

$<$ 解説 $>$

患者からの電話連絡，あるいは患者が来院した救 急外来の受付で感染症に罹患している可能性のある 患者をスクリーニングするためのチェックリストが 必要である9（図 2）。

新興感染症を行政通知に基づき渡航歴と症状から スクリーニングし隔離エリアに誘導する。さらに, 必要に応じて症状や接触歴から空気感染，飛沫感 染，接触感染する疾患をスクリーニングして，隔離 エリアに誘導する。事務員が短時間で聴取すること を想定し，問診項目は紙面を用いたチェックリスト 形式で準備する。スクリーニング対象は各施設の事 情に合わせて検討する。

新興感染症については，行政の通知に従い該当す る国や地域への渡航歴と症状からスクリーニングす る。

肺結核のスクリーニングにあたって有用性が確認 されている病歴は発熱と体重減少であるが，危機管 理の観点からは，その他に 3 週間以上続く咳があ る，痰に血が混じる，周囲に結核の方がいるなどの 問診項目が想定される ${ }^{17) 。 ~}$

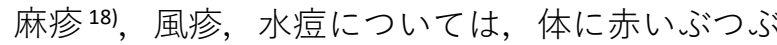
つ（発疹）がある，発熱の有無について確認し，さ らに麻疹や水痘患者との接触歴を確認する。問診上 は，はしか（麻疹），風疹（三日ばしか），水ぼう そう（水痘），帯状疮疹，など異なる呼び名がある ことに注意が必要である。

嘔吐・下痢の激しい患者，ノロウイルス等につい ては，吐物がエアロゾル化し伝播の要因となる ${ }^{19) 。 ~}$ 使用するトイレについても，他の患者と異なる場所 を利用するように指導する ${ }^{20) 。 ~}$ 
渡航歴についてく中国, アラビア半島, アフリカ大陸またはその周辺諸国〉

ご本人あるいはご家族の方で，上記の国への渡航が 14 日以内にあ

り，かつ

感冒症状（発熱，せき，鼻水）がある力はいますか?

ロはい yes $\square$ いいえ no

Within the last 14 days, have you or anyone in your family traveled to any countries in the Arabian Peninsula, Africa or China and have symptoms of cold (fever, cough, runny nose)?

3 週間以上続くせき，掞（たん）に血が混じるなどの症状はありま すか?

$\square$ はい yes $\square$ いいえ no

Have you had cough lasting more than 3 wecks or have sputum mixed with blood?

3 週間前から今日までの間で，ご本人および家族のいずれの方が， 結核・はしか・水ぼうそう・おたふくかぜ・带状疱疹の感染者と 接触しましたか?

$\square$ はい yes $\square$ いいえ no

Have you or anyone in your family come into contact with a person who has Mumps, Tuberculosis, Measles, Chickenpox, or Herpes zoster (shingles) in the past 3 weeks?

発疹（ぶつぶつ）在伴うような発熱はありませんか?

$\square$ はい yes $\square$ いいえ no

Do you currently have fever and rash?

図 2. 感染症問診票例

上記内容を推奨するものではなく，各施設の状況に応じて作成。

新興感染症の場合には症例定義などを含めて，行 政からの通知があるたびに再作成が必要である。

項目 13. 電話連絡の場合, 患者を適切な入口へ誘導 できる説明体制があり，感染症が疑われる受診患者 を適切な入口へ誘導する見やすい掲示がある。

<カテゴリー>

四半期（常時）及び臨時
$<$ 解説 $>$

$S A R S^{21)}$ や $M E R S^{4)}$ 感染者の多くは救急外来を含む 病院における伝播事例であり，国内外の機関から救 急外来における対応の強化が求められている ${ }^{9)}$ 。そ の他, 通年性の一般的な感染症, インフルエンザや ノロウイルスに代表される季節性疾患も他の患者に 伝播するリスクがある。

項目 12 に従い感染症を問診でスクリーニングし, 
掲示文例

発熱, 発疹, 咳, 嘔吐, 下痢のある方は受付スタッフまで 申し出ください

発熱，咳のある方はマスクを着用ください。救急外来入口 のマスク販売機をご利用ください

1 か月以内に○○に滞在され, 発熱, 咳などがある方は受 付スタッフまで申し出ください

図 3. 掲示文例

リスクのある患者がいた場合，他の患者との不用意 な接触を避けるために誘導する。事前の電話連絡の 場合は専用の入り口への誘導あるいは車の中での待 機などが考えられる。なお，重症度が高い場合は， スタッフに感染症状について連絡したうえで，初療 室（個室）に誘導するなどの対応を検討する。

掲示は患者・付き添い者・面会者を対象としたも ので，平易な文言や図で記載され具体的な行動につ ながることが重要である（図3）。目的は感染症の ある患者を適切な場所に誘導すること，あるいは感 染対策の実施につなげることである9

所定の場所に誘導した後に，考慮すべき点として 下記が挙げられる。

患者に手洗いをお願いする。咳嗽・鼻汁など呼吸 器症状がある場合は原則サージカルマスクの着用を お願いする。ただし，着用が困難な乳幼児，呼吸障 害の強い患者については，患者間の距離を $1 \mathrm{~m}$ 以上 保つことを指示する。サージカルマスクの販売機と ともに正しい着用方法の掲示があることが望まし い。

インフルェンザ流行期はサージカルマスク着用を 促す。

下痢，嘔吐のある患者については，利用するトイ
レを指定し，石鹸と流水による手洗いを案内する ${ }^{20) 。 ~}$ 新興感染症の場合には症例定義などを含めて，行 政からの通知があるたびに再作成が必要である。

\section{項目 14. 患者の対応にあたる場合は，救急外来の受} 付職員を含め, 救急外来職員はサージカルマスク着 用を原則とする。

<カテゴリー>

四半期（常時）及び臨時

$<$ 解説 $>$

救急外来の職員は，急性呼吸器感染症に曝露する 機会が多く，職種に限らず患者接触時にはサージカ ルマスクの着用が必須である 22, 23)。職員間の伝播報 告も知られている ${ }^{24)}$ 。急性感染症の多くは, 発症前 数日からウイルス等を排泄することが知られてお り，患者を診療している以外の時も，救急外来では 着用を原則とする。

呼吸器感染症の患者を診察した後は，サージカル マスクなど個人防護具（PPE）の表面は污染されて いると考え，交換が原則となる ${ }^{25)}$ 。正しいサージカ ルマスクの着脱方法を習得するとともに，前後の手 指衛生が必須である。エボラウイルスの伝播におい ても，個人防護具（PPE）の不適切な使用が伝播要 
因となり多くの医療従事者が犠牲になっている ${ }^{26) 。 ~}$ 湿性体液に曝露される手技を実施する場合は，エア ロゾル化が想定され，サージカルマスクに加えてア イシールドが必要となる。

空気感染を疑う場合, 一部の新興感染症の対応に は，サージカルマスクは不適切である。結核に対し ては，N95 マスクの着用が必要であり，麻疹・水痘 については免疫が確認されている職員が診療にあた る ${ }^{14)}$ 。

新興感染症の場合には症例定義などを含めて，行 政からの通知があるたびに再作成が必要である。

項目 15. 受付事務員を含む救急外来スタッフがトリ アージをするための問診票あるいは質問票（渡航先 及び滞在期間，感染症曝露の可能性の有無を含む） を日本語と外国語（英語のほか，感染症流行地で使 用される言語を含むことが望ましい）で用意してい る。

$<$ カゴリー＞

四半期（常時）及び臨時

$<$ 解説 $>$

項目 12 で示した対応を確実に実施する為には，事 務員が重症度判断，感染経路の推定に関する質問票 が必要である 27)。

日本語の他に，英語，中国語，韓国語など他言語 のものがあることが理想的だが，各施設が独自で用 意することは困難で，公表されているものなどで代 用する ${ }^{28)}$ 。

新興感染症の場合には症例定義などを含めて，行 政からの通知があるたびに再作成が必要であり，臨 時・四半期ごとに内容をアップデートする。

\section{項目 16. 感染スクリーニング体制が敷かれている。}

<カテゴリー>

年 1 回

$<$ 解説 $>$

救急外来は，感染症に遭遇するリスクが高い場所 であり，受診した患者を渡航歴や症状に応じてコ
ホートするための体制が必要である。12-17 項で示 した対応を実施する為のシステムは，複数の部門や 職種の協力が必要であり，院内の取り決めとして整 備する必要がある ${ }^{29) 。 ~}$

実際の手順例を図 4 に示す。スクリーニングは問 診票に基づき実施するが，「誰が，どこで」行うか を明確にすることが必要である。

患者来院から受付，診察にいたるまでの業務の流 れのなかに，感染症のスクリーニングを組み込むこ とで円滑な対応が可能となる。まず問診票で発熱や 発疹，呼吸器症状の有無を確認し，また患者からの 申し出を促すための揭示物を作成する。さらに各職 員の役割を明確にし，取りこぼしのないような 2 重・3 重のセーフティネットを構築する。例えば, 受付職員は呼吸器症状のある患者に対してサージカ ルマスクの着用を依頼し，所定の待合場所に案内 し，トリアージナースに連絡する。トリアージナー スは，症状や病歴から想定される病原体に対する感 染経路別予防策の詳細を指示する。診療にあたる医 師は，診断に基づき隔離解除の判断を管理者や ICT と相談し実施する。各病院の組織，構造，リソース によって対応は異なり，現場を中心とした調整が必 要である。

項目 17. 新型インフルエンザなど新興・再興感染症 流行時には，疑い例を含む症例定義に基づく感染ス クリーニング体制が強化される。

<カテゴリー>

臨時

$<$ 解説 $>$

通常の感染スクリーニング体制に加えて，特定の 感染症が流行した場合には，その感染経路や危険 性に応じてその体制を速やかに強化する必要があ る ${ }^{29)}$ 。行政連絡から，体制強化，連絡通知に至る手 順を院內の決定事項として明文化してあることが必 要である（図 5 参照）。

特定の感染症が流行した際には，行政からの通知 が院内の事務担当者に送付される。院内の事務担当 

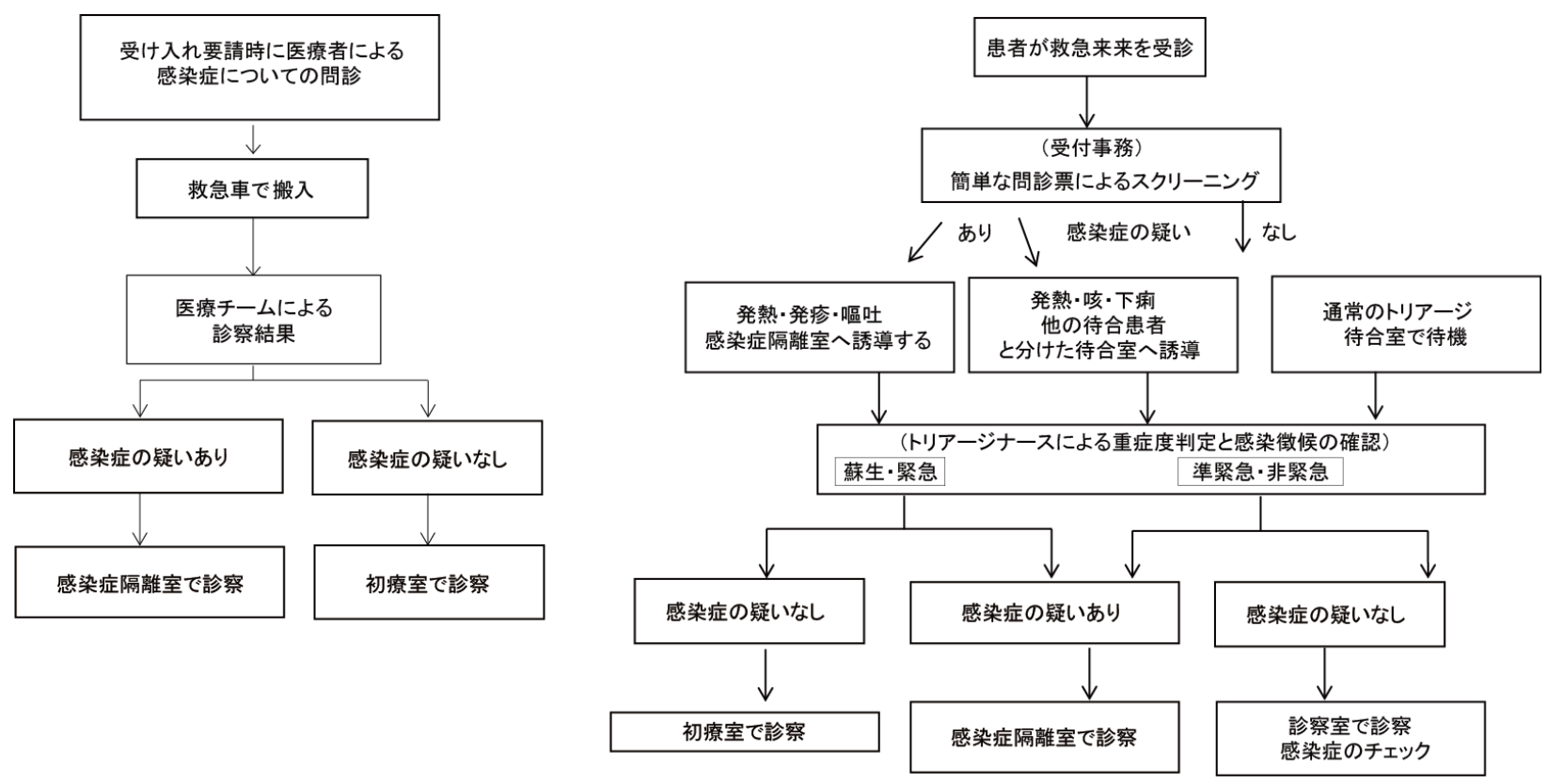

図 4. 感染スクリーニング例

各病院におけるシステムの確認として，年に 1 回実施する。

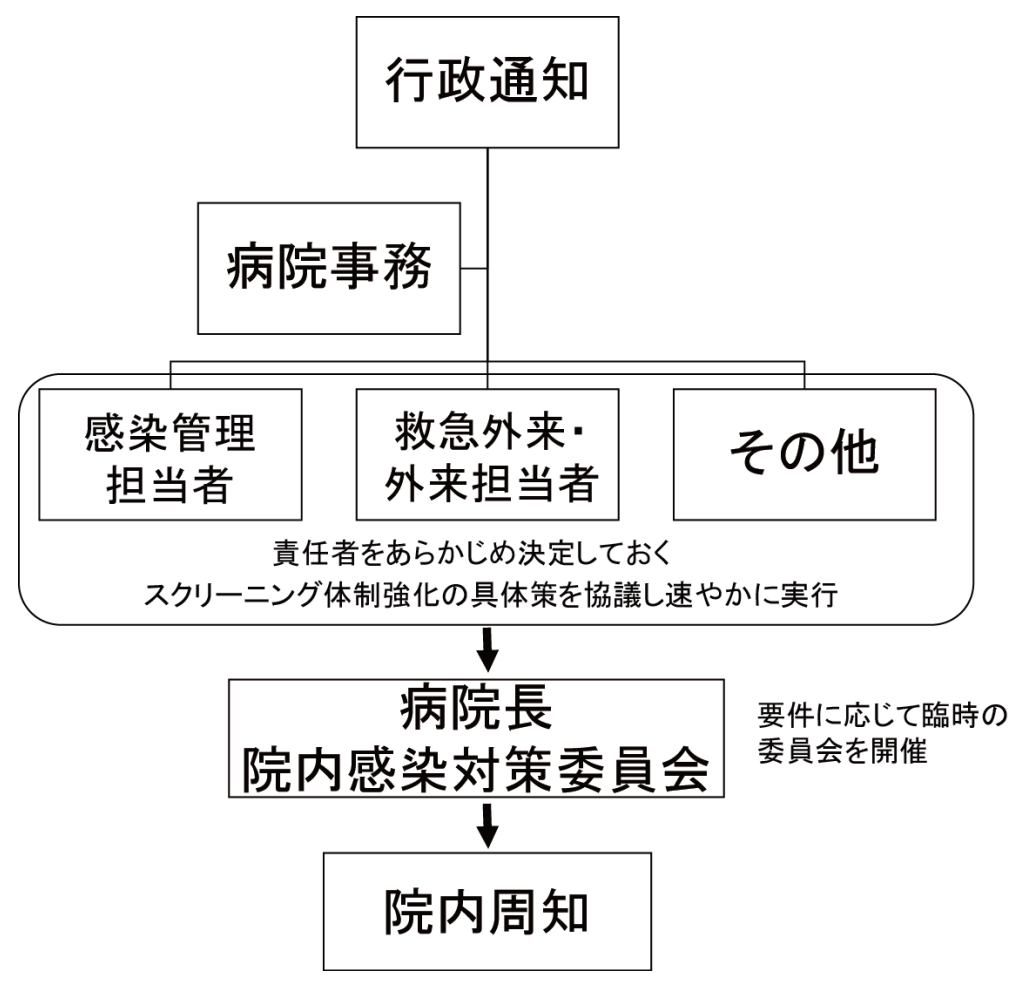

図 5. 感染スクリーニング体制の強化

各病院におけるシステムの確認として, 年に 1 回実施する。 
者は，これを受け必要部署に連絡をする。連絡先は 通常，院内の感染管理担当者であるが，施設の状況 に応じて救急外来担当者やその他の部門に連絡を行 う。

臨時でスクリーニング体制を強化するにあたり， あらかじめ責任者を明確にしておく必要がある。通 知を受けた責任者は，救急外来担当者を含む関係者 と協議のうえで，具体的な方策を提示し，実行する 権限を持つことが重要である。必要最低限の対応は 現場の判断で速やかに実施可能でなければならな い。対応する疾患や状況に応じて，必要であれば臨 時院内感染防止対策委員会など，病院幹部を含む会 議で協議のうえ決定事項を院内に周知する。

項目 18. 陰圧, HEPA フィルターなどが備えられて いる特殊または専用診察室への患者および医療従事 者の動線が周知され実施されている。

<カテゴリー>

四半期（常時）及び臨時

$<$ 解説 $>$

陰圧，HEPA フィルターなどが備えられている特 殊または専用診察室（項目 42 参照）は，空気予防 策の適用患者（肺結核，麻疹，水痘/播種性帯状疮 疹：すべて疑いを含む）で使用する。患者の排出す る飛沫核の遮蔽と拡散防止のために，速やかに当該 診察室に隔離をする必要がある9)。呼吸器症状を認 める場合には，感染経路別予防策に係る患者選別の ため，受付等と連携して迅速に対応できるよう対応 手順や患者や付き添い者への啓発のための個人防護 具（PPE）着用や動線の案内が必要である。感染性 のある患者を遅滞なく当該診察室に案内すること は，職業曝露および一般待合い区域等における曝露 者数を最小限にすることができる。こうした対応の ハード面, ソフト面の確認は, 平時より確認・周知 することが有事の際の予防対応として必要である。

項目 19. 主な症状別（発熱・発疹，消化器症状，呼 吸器症状）に基本的な動線，隔離方法，対応がマ

\section{ニュアル化され，感染症が疑われる患者の動線とそ} の他の患者および職員の動線が適切に設定されてい

る。

<カテゴリー>

四半期（常時）

$<$ 解説 $>$

患者が伝染性感染症の症状や徵候を呈した時点, または医療施設に到着した時点で適切な感染経路別 予防策を実施すれば，伝播リスクを減少させること ができる9)。

感染経路別予防策が必要な患者すべてを想定して 対応することは困難であるが，検査結果を待つ間に 感染経路別予防策を経験的に実施することが推奨さ れる 9)。また，患者移動時と待合時の曝露防止への 配慮も必要であるため，来院〜受付〜待合場所の指 定または誘導および代替案については，新感染症や 指定感染症等の対応を目的とした手順の整備が必要 である。

患者動線の確保や空間分離は，患者との接触を避 けることを目的として行われ，主に新興感染症を想 定した場合の付加的措置であり，多少議論の余地は あるが，混雑するエリアへの立ち入りを制限する目 的で行うことは，経路別予防策の一環および基礎疾 患を有する者への感染対策（平成 21 年 6 月 19 日厚 生労働省医療の確保，検疫，学校・保育施設等の臨 時休業の要請等に関する運用指針改定版）として一 定のコンセンサスを得られるものである。

1. 患者動線を考える際の留意点（空気感染または その疑い)

1) 専用または指定された入り口からの出入り （事前連絡が望ましい）。

2) 専用の待ち合い室での待機（陰圧空調, HEPA フィルター空気清浄，安全確保のうえ空開 放)。

3) 検査，その他移動時の専用通路確保，または 混雑エリアを避ける配慮。

2. 患者動線を考える際の留意点（飛沫感染または 
その疑い)

1) 専用の待ち合い室の使用，または待合エリア の空間分離。

2) 検査，その他移動時は混雑エリアを避ける配 慮。

3. その他共通

1)症状スクリーニング

2) 患者, 職員の咳エチケットの励行

3) アナウンス，掲示等の対応

4) 対応職員への周知

\section{(2) 感染予防の具体策}

項目 20. 標準予防策に必要な個人防護具（PPE）は, 各種サイズを十分量かつ必要なときにすぐ使えるよ うに整っている。

<カテゴリー>

四半期（常時）及び臨時

$<$ 解説 $>$

ギニア，リベリア及びシエラレオネにおける 2014～2016 年のエボラウイルス感染症の流行にお いて，医療従事者は一般市民よりも 21～32 倍感染 リスクが高かったこと，現場の最前線で働く医療従 事者の個人防護具（PPE）の不適切使用または不足 がその原因の一つであったと報告されている30)。こ の報告は，感染対策に必要な物品が各サイズにおい て十分量あり，すぐ使えることが重要であることを 示唆している。本邦の感染防止対策地域連携加算 チェック項目に「必要なときにすぐ使えるように個 人防護具（PPE）が整っている」という項目が挙げ られていることからも，その重要性が理解できる。 常日頃より不足がないように確認することも大切で あるが，四半期毎に使用量の調査を行い，必要量を 検討しておく。

また，不特定多数の患者を診療する救急外来にお いては，予測できない結核患者との接触も考えられ るため，救急外来にN95 マスクを用意しておくこ とが大切である。
なお，感染予防に関する物品の備蓄についてであ るが，平時においては標準予防策並びに経路別予防 策に準じた個人防護具（PPE）が不足しない程度あ れば良いと考える。パンデミック時は，個人防護具 （PPE）備蓄期間の目安を 8 週間程度と試算している 報告もある ${ }^{31)}$ が，行政の行動計画・ガイドライン に従い備蓄すべきである32)。

項目 21. 外傷, 嘔吐など症状に応じて，感染制御に 必要な物品をすぐに使用できるよう準備している。

<カテゴリー＞

四半期（常時）

$<$ 解説 $>$

項目 20 で述べたように，予防に必要な物品が十 分量かつすぐ使えることが感染予防において，重要 である。救急外来には，様々な症状の患者が受診す るため, 即座の対応が難しいこともあり，標準予防 策並びに経路別予防策に準じた必要物品のセット化 が，感染対策上，有用と考えられる。セット化する に当たっては，使用する物品の一包化の他，棚別に 物品をまとめておく・症状や経路別に応じたカート を作っておく等の方法が考えられる。

項目 22. 末梢静脈ラインを確保する場合にも，院内 のマニュアルに沿って清潔操作を行っている。

<カテゴリー>

四半期（常時）

$<$ 解説 $>$

末梢静脈カテーテルを原因としたカテーテル関連 血流感染症（CRBSI）は 0～2.2\%と報告されており 33)，一般に留置期間が短いため CRBSI 発生率は低い とされる。

しかし，救急外来における末梢静脈ライン確保 は, CRBSI 発生率が有意に増加するとの報告もあり 8, 34)，緊急を要する状況において感染対策が不十分 になっている可能性を示唆している。

また，アトピー性皮膚炎や尋常性乾癬などにより 慢性皮膚病変を有するあるいは皮膚保清が不十分な 
患者ではブドウ球菌やバチルス属などの皮膚常在菌 が増殖しており，末梢カテーテル確保における血流 感染のリスクは高くなる。

患者の高齢化に伴い，皮膚病変や保清不十分な患 者も増えており，末梢静脈ライン確保をより一層注 意して行う必要がある。

\section{項目 23. 感染が疑われない場合であっても，気管挿 管を行う際には，標準予防策（手袋，アイガード, サージカルマスク等）が実施されている。}

<カテゴリー＞

四半期（常時）

$<$ 解説 $>$

標準予防策は，「すべての患者の血液，体液，分 泌物, 嘔吐物, 排泄物, 創傷皮膚, 粘膜などは, 感 染する危険性があるものとして取り扱わなければな らない」という考えに基づいている。これは，原因 微生物別あるいは疾患特異的な感染対策ではなく, 感染症の診断が確定する前からの非特異的な感染対 策を行うことが必要であることを示している。ま た，病原体を伝播し得る体液/分泌物/浸出液を感染 媒体とみなした感染対策を行うことを求めている 35)。病原体の伝播リスクが一貫して高いエアロゾル 発生手技に際しては，手袋，長袖ガウン，眼の保護 具（ゴーグルまたはフェイスシールド）および顔面 マスク（サージカルマスク，処置用マスク，または 微粒子レスピレーター）などの個人防護具（PPE） を使用する。現在得られているエビデンスでは，気 管挿管を単独で，あるいは他の手技（心肺蘇生また は気管支鏡検査など）と併用で実施した場合，伝播 リスクが一貫して高いことが示唆されている ${ }^{36)}$ 。以 上より，感染が疑われない患者であっても，気管挿 管時には気道や口腔内の分泌物や血液に曝露する危 険性があることから，標準予防策の遵守は必要であ る。

\section{項目 24. 入院が決定した患者に対し，尿道カテーテ ルをルーチンに挿入していない。}

<カテゴリー＞

四半期 (常時)

$<$ 解説 $>$

尿路感染症は医療関連感染の約 40\%を占めてお り，約 80\%は尿道カテーテル留置が原因であると報 告されている ${ }^{37,38)}$ 。尿道カテーテル留置は, 留置そ のものが尿路感染のリスクとなることより，入院患 者に対して不必要な尿道カテーテル挿入を行わない ことが，尿路感染ならびに医療関連感染の予防とな

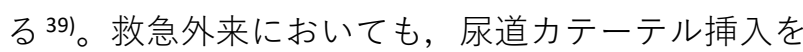
ルーチンに行うことなく，適応を検討することが感 染対策において非常に重要である。なお，尿道力 テーテルの適応として，急性の尿閉や膀胱排尿障害 などが挙げられており，留置は必要な期間に留める ことが推奨されている。女性・高齢者・免疫機能障 害者のようなリスクが高い患者においては，尿道力 テーテル挿入に当たり，より慎重な検討が必要とさ れている。

\section{項目 25. 尿道カテーテル挿入は無菌操作で行われて}

いる。

<カテゴリー>

四半期 (常時)

$<$ 解説 $>$

項目 24 で述べたように，尿路感染症は医療関連感 染の約 40\%を占めており，約 $80 \%$ が尿道カテーテル

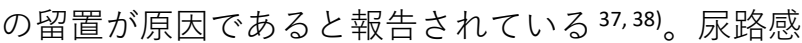
染をできるだけ予防するために，尿道カテーテル挿 入では無菌操作に留意し，尿の逆流と回路からの細 菌の侵入を防止する必要がある ${ }^{40)}$ 。無菌的手技とし

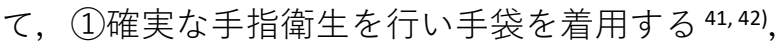
(2)滅菌手袋・ドレープ・スポンジ・潤滑ゼリ一等滅 菌器材を使用する，(3)カテーテル挿入前の尿道口周 囲の洗浄に適切な消毒薬あるいは滅菌溶液を使用す る，(4)カテーテルの無菌的挿入後は閉鎖式排尿回路 を維持すること ${ }^{39,42)}$ が具体的に挙げられている。 感染管理者は, 四半期毎に, 尿道カテーテル挿入が 無菌操作で行われているかの確認と, 無菌操作が行 
われていない場合は指導ならびに再確認を行う。

項目 26. 血液体液曝露の危険がある患者の診察や胸 腔ドレナージ，腰椎穿刺等施行時にはアイガード, サージカルマスクを使用している。

<カテゴリー＞

四半期 (常時)

$<$ 解説 $>$

項目 23 でも述べたが，標準予防策は，「すべての 患者の血液, 体液, 分泌物, 嘔吐物, 排泄物, 創傷 皮膚，粘膜などは，感染する危険性があるものとし て取り扱わなければならない」という考えに基づい て行われる35)。

この考えに基づき，胸腔ドレナージ・腰椎穿刺・ 血液体液曝露の危険がある患者の診察において，標 準予防策を遵守すべきである。また，血液体液に曝 露した組織別の統計において，眼が 60.1\%と他の組 織に比べて多く, 防護していない皮膚・粘膜への曝 露が 82.1\%であったとの報告 ${ }^{43)}$ からも，アイガード の使用についてはとりわけ注意し, 徹底する必要が ある。

\section{項目 27. 中心静脈カテーテル挿入は適応を慎重に吟} 味し，実施する場合には CLABSI prevention bundle を遵守している。

<カテゴリー＞

四半期（常時）

$<$ 解説 $>$

院內における血流感染の多くは血管内留置カテー テルに関連している。カテーテル関連血流感染症 （CRBSI）発生率は末梢静脈カテーテルよりも中心静 脈力テーテルの方が高く ${ }^{44)}$, 救急外来で挿入された 場合，中心ライン関連血流感染症（CLABSI）発生率 は 1.93/1,000catheter-days であったと報告されてい る。CLABSI は院内死亡率を上昇させるリスク因子で あり ${ }^{45)}, \mathrm{CLABSI}$ 予防に最も有効であるのは，不適切 な中心静脈カテーテル挿入を行わないことである。 中心静脈カテーテルが必要であると判断した場合
は，CLABSI prevention bundleを実施する ${ }^{46)}$ )CLABS prevention bundle は，CLABSI 予防に有用とされてい る以下の 5 項目から構成される。(1)カテーテル挿入 前に抗菌石鹸またはアルコール含有製剤による手指 消毒を行う，(2)中心静脈カテーテル挿入は maximal sterile barrier precautions（MSBP）で行う，(3)中心静 脈カテーテル挿入前の皮膚消毒は $0.5 \%$ を超える濃 度のクロルヘキシジンで行い，消毒薬が乾いてから カテーテルを刺入する，(4)中心静脈カテーテル穿刺 部位として大腿静脈を避ける，(5)不要になった力 テーテルは速やかに抜去する。

項目 28. 中心静脈カテーテルを挿入する場合には, 手技を行っている以外の医療従事者により清潔操作 維持を監視し，違反があった場合には手技を中止し ている。

<カテゴリー>

四半期（常時）

$<$ 解説 $>$

項目 27 で述べたように，中心静脈カテーテルを挿 入する場合, CLABSI prevention bundle を実施する ${ }^{46) 。 ~}$ 救急外来において，時間的制約と煩雑な状況から， 清潔操作が困難な場合もあるが，CLABSI prevention bundle を遵守するように努める。そのためには, 中心静脈カテーテルの不要な挿入を避け，監視下で 行うことが有用と考える。なお，「必須行為の省略 があった場合，中心静脈カテーテル挿入中止の権限 を看護師に持たせる」という項目を含んだ介入を行 い, 清潔操作の遵守率の向上かつ CLABSI 発生率の

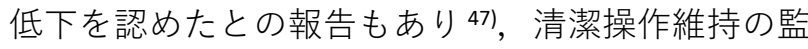
視は bundle 遵守率の向上ならびに CLABSI 発生率の 低下に繋がると考えられる。

項目 29. 感染につながる曝露が疑われる場合の対処 手順が整備されている。

<カテゴリー＞

年 1 回

<解説 $>$ 
表 1. 曝露後の対処

\begin{tabular}{|c|c|}
\hline B 型肝炎 & $\begin{array}{l}\mathrm{HBs} \text { 抗体 }(+) \text { : 処置不要 } \\
\mathrm{HBs} \text { 抗体 }(-) \text { : HBIG + HB ワクチン }\end{array}$ \\
\hline C 型肝炎 & モニタリング（HCV-RNA，肝機能） \\
\hline HIV/AIDS & 抗ウイルス薬 (エムトリシタビン・テノホビル + ラルテグラビル $)$ \\
\hline 重症熱性血小板減少症候群（SFTS） & 2 週間モニタリング（症状，血球計算） \\
\hline \multicolumn{2}{|c|}{ 飛沫・飛沫核曝露後の対処（接触者に免疫がない・不明の場合）50,51) } \\
\hline 麻疹 & $\begin{array}{l}72 \text { 時間以内：麻疹含有ワクチン } \\
6 \text { 日以内 +妊娠など免疫不全あり：グロブリン }\end{array}$ \\
\hline ムンプス & 3 週間モニタリング \\
\hline 風疹 & 3 週間モニタリング \\
\hline 水痘 & $\begin{array}{l}72 \text { 時間以内 : 水痘ワクチン } \\
7 \text { 日以内 : アシクロビル }\end{array}$ \\
\hline 髄膜炎菌感染症 & シプロフロキサシン \\
\hline 結核 & 接触者検診 \\
\hline 鳥インフルエンザ（H5N1・H7N9） & オセルタミビル \\
\hline
\end{tabular}

外傷や出血症状のある患者を診療することが多 く，侵襲的な医療行為を行うことも少なくない救急 外来では血液・体液の針刺し・粘膜曝露が発生する リスクは一般に高いと考えられる5)。B 型および C 型肝炎ウイルス，ヒト免疫不全ウイルス，重症熱性 血小板減少症候群（SFTS）ウイルスなどが陽性の血 液・体液の曝露があった場合には，曝露部位を流水 で洗浄するとともに，感染リスクに応じて，曝露後 発症予防処置や検診が行われる必要がある 48,49 )。ま た，飛沫・飛沫核感染する疾患のうち，麻疹，風 疹，水痘，ムンプスでは事前の免疫の確認が重要で ある ${ }^{48)}$ 。免疫がない，あるいは不明な職員が曝露を 受けた場合は，ワクチンやグロブリン，抗ウイルス 薬の投与を検討する（表 1 参照） 50 )。髄膜炎菌感染 症の患者に接触した場合には，医療従事者が患者に 行った医療行為や着用していた個人防護具（PPE） に応じて，感染リスクを評価し，抗菌薬の適応を検 討する必要がある。いずれも緊急性を要するため, 感染リスクが高い曝露については手順をマニュアル に記載するとともに，院内の感染制御の専門家に 24 時間体制で相談できるようにしておくことが肝 要である。救急外来で結核患者と接触があった場合
のリスク別対応手順を保健所と相談して決めておく ことが望ましい12)。

\section{(3) 環境整備}

項目 30. 使用後診察室の清掃, 高頻度接触面や污染 箇所の環境整備（湿式），アルコール抵抗性の微生 物に対する適切な薬剂と濃度に関する手順が周知徹 底されている。

<カテゴリー>

四半期（常時）及び臨時

$<$ 解説 $>$

診察室の清掃および表面消毒は，救急外来部門に おいても病院全般と同様に重要である。埃や砂な ど，あるいは目に見えない微生物を物理的に取り除 〈のが清掃である7)。清掃の際は，界面活性剤や洗 剤，水などを用いてブラシやモップなどを使用す る。超音波クリーナーなどの器械を使用することも ある。清掃により多くの微生物を除去することがで きる。消毒のみを単独で行っても効果は限定的であ る。消毒を行う前に清掃を行うことが必須である。 消毒は，滅菌に比べて微生物を不活性化する程度は 
弱いが，消毒によりほぼすべての微生物を除去する ことができる。しかし，芽胞などは不活性化できな いことに注意する。

救急外来部門における清掃および表面消毒につい て, 救急外来部門の特殊性を理解しておく必要があ る。初期診療を行う診察室（あるいは診察スペー ス）は，患者が頻繁に入れ替わる。受診患者が多い 時は，前の患者が移動した後，すぐにその診察室で 新たな患者を診察する必要が生じる。患者の診察を 急ぐあまりに，清掃および表面消毒を省略してはな らない。患者や医療従事者への二次感染を防ぐため にも清掃および表面消毒は必須である。空いた診察 室を迅速に清掃および表面消毒を行うシステムを確 立しておく必要がある。また患者が多剤耐性菌を有 している場合でも，患者が救急外来部門を退室して 他病棟などに入院した後に培養などの結果が判明す ることが多い。その場合に，確実に救急外来部門に 情報が入り，適切な消毒を行うことができる院内の 情報伝達システムを確立しておく必要がある。ま た，多剤耐性菌排菌患者に備えて，複数種類の消毒 薬を用意し，使い分けをわかりやすく表示し，説明 書に沿って適切に使用することが必要である7。例 えば, MRSA, VRE, Clostridioides (Clostridium) difficile などを排菌している患者を収容している環 境においては，手が触れる環境表面は，4 級アンモ ニウム塩またはアルコールを用いることが推奨され ている52)。またウイルスは環境中で比較的長時間生 存できるので，ウイルス感染症患者の診察後の環境

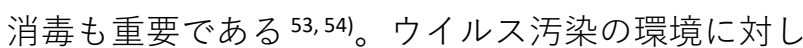
ては，アルコールや次亜塩素酸ナトリウムを用い る。エンベロープがないウイルスはアルコール抵抗 性を有するので，注意が必要である。アルコール抵 抗性が強いウイルスには，ノロウイルス，A型肝炎ウ イルス，ロタウイルス，ポリオウイルス，コクサッ キーウイルス，エコーウイルスなどがある ${ }^{55,56) 。 こ ~}$ れらのウイルスに対しては，次亜塩素酸ナトリウム を用いる。ただし，次亜塩素酸ナトリウムは，金属 に対する腐食作用，䋊維製品に対する漂泊作用があ
る。また木材と接触すると効力が減弱する。このよ うな対象物にはアルコールを用いる。アルコールを 用いる場合は，消毒対象物に対して二度拭きをして

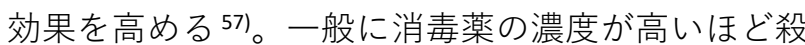
菌効果は上がるが，被消毒物に与える影響も考慮す る必要がある。消毒薬は下記のように様々な状況で 濃度が低下している可能性があるので，使用時や管 理に注意を要する。低水準消毒薬（クロルヘキシジ ングルコン酸塩など）や，ポビドンヨード，次亜塩 素酸ナトリウムなどは有機物混入により濃度が低下 する。低水準消毒薬のなかには消毒綿やモップなど の䋊維に吸着され，濃度低下を起こすものもある。 次亜塩素酸ナトリウムは時間経過とともに濃度が低 下する。アルコール製剤は揮発により濃度が低下す る。

1 年に 1 回あるいは四半期に 1 回，上記の事項が できていることを確認する7。。また多剤耐性菌など のアウトブレイク時には，臨時に確認する。

項目 31. 再利用可能な機器 (超音波, 血糖測定など のポイントオブケア物品，内視鏡など）は次の患者 に使用される前に適切に洗浄・消毒・滅菌されてい

る。

<カテゴリー>

四半期（常時）

項目 32. 再利用可能な機器を洗浄・消毒・滅菌する 場合には適切に個人防護具（PPE）を使用している。

<カテゴリー>

四半期（常時），臨時

項目 33. 再利用（洗浄・消毒・滅菌）の手順を Handson で教育している。

<カテゴリー＞

年 1 回及び特定

$<$ 解説 $>$

救急外来部門にある医療機器・器具が単回使用の ものか，あるいは再利用可能なものかを把握してお 
表 2. Spaulding の分類

\begin{tabular}{|c|c|c|c|}
\hline 分類 & 用途 & 例 & 消毒, 滅菌の程度 \\
\hline $\begin{array}{l}\text { クリティカル器具 } \\
\text { Critical items }\end{array}$ & 無菌組織や血管内に挿入するもの & 手術器具 & 滅菌 \\
\hline $\begin{array}{l}\text { セミクリティカル器具 } \\
\text { Semi-critical items }\end{array}$ & $\begin{array}{l}\text { 粘膜あるいは健常ではない皮膚に } \\
\text { 接触するもの }\end{array}$ & $\begin{array}{l}\text { 上部あるいは } \\
\text { 下部消化器内視鏡 }\end{array}$ & 高水準消毒 \\
\hline $\begin{array}{l}\text { ノンクリティカル器具 } \\
\text { Noncritical items }\end{array}$ & $\begin{array}{l}\text { 正常な皮膚に接触するもの } \\
\text { （粘膜には接触しない） }\end{array}$ & 血圧測定用のカフ, 聴診器 & 低から中水準消毒 \\
\hline
\end{tabular}

く必要がある。血糖測定などのポイントオブケア物 品，消化器内視鏡，気管支鏡，切開縫合のための手 術器具, 針, などたくさんの機器が救急外来部門に ある。患者患者間の水平感染を防ぐために，すべて の再利用可能な医療機器は説明書に沿って適切に洗 浄し,メンテナンスしなければならない7。これに 関しては下記の Spaulding の分類が参考になる（表 2 参照) ${ }^{58)}$ 。Spaulding の分類は，水平感染のリスクを もとに，どの程度の滅菌あるいは消毒が必要かにつ いて再利用可能機器を分類したものである。

機器に污机が残っていると消毒や滅菌の効果が不 十分になるため, 消毒や滅菌の前には洗浄が必要で ある7)。

血糖測定用などに使う微量採血のための穿刺器具 には，以下の 3 種類がある。(1)器具全体がディス ポーザブルの製品であり，単回使用専用であるも の，(2)穿刺針ならびに周辺部分がディスポーザブル の製品で，針の周辺を含めて交換するために複数人 に使用が可能であるもの，(3)穿刺針は交換するが, 穿刺針の周辺がディスポーザブルではないもの。こ のため前回の採血で污染された場合には，交換した 穿刺針が污染される可能性があり，(2)と異なり複数 人への使用ができないので注意を要する。消化器内 視鏡の洗浄や消毒に関しても,「消化器内視鏡の感染 制御に関するマルチソサイエティ実践ガイド，改訂 版」が公表されており，参考にするべきである59)。

再利用可能な医療機器を清潔に適切に使用できる ように，機器の説明書を容易に参考にできるように しておくべきである7。再利用可能な機器を洗浄, 消毒，滅菌するときには，医療従事者自身への感染 や医療従事者を介しての患者への感染を防ぐために
個人防護具（PPE）を使用する。個人防護具（PPE） は標準予防策の範疇でよい。各再利用可能な機器の 洗浄，消毒，滅菌の適切な方法とその際に適切な個 人防護具（PPE）を使用することを 1 年に 1 回およ び新しい機器を導入した場合や方法を変更する場合 などにハンズオントレーニングを行う》。機器の洗 浄，消毒，滅菌を主に行う者に限定せず，部門全体 に周知して教育することが重要である。

\section{(2) 院外}

\section{(4) 救急搬送}

項目 34. 病院前救護活動を行う職員からの情報に基 づき，病院前救護活動を行う職員に対し適切な感染 防止対策を指示している，あるいはすることができ る。

<カテゴリー＞

特定及び臨時

$<$ 解説 $>$

感染が疑われる全ての傷病者と接する時は，標準 予防策が基本である 9)。さらに，何か感染対策に関 連した事象が発生した場合，収容する予定の医療機 関，所轄保健所・衛生局等との情報伝達と共有が重 要である。概念的には，市中で季節性に蔓延してい る感染性疾患と, 海外から侵入してくる可能性のあ る感染性疾患と大きく 2 通りある。

前者は，小児では夏から秋にかけてインフルエン ザ流行に先行する RS ウイルス感染 ${ }^{60)}$ ，秋から冬に かけて感染性胃腸炎（特にノロウイルス），冬から 春にかけてインフルエンザ等が該当する。感染性胃 腸炎とインフルエンザに関しては，標準予防策に感 
染経路別予防策を講じつつ ${ }^{9}$ ，搬送先にその情報を 確実に伝達する（カテゴリー：特定）。

後者は, 関心度が低くなりつつあるが中東で集団 感染が未だに絶えない中東呼吸器症候群 611 を始 め，日本では稀もしくは経験のない新興・再興感染 症への備えは, 海外渡航・居住歴のある傷病者と接 する場合に生じる。公的な情報は厚生労働省検疫所 （FORTH）ホームページで開示されている。病歴聴 取時に，傷病者が侵淫地域に渡航・居住している情 報を得た場合，標準予防策にどの感染経路別予防策 を講じるかの判断も含め，搬送予定の医療機関もし くは所轄保健所・衛生局に連絡を入れ，搬送先，搬 送時の感染対策等の指示を受けるようにする。その 他に，西日本を中心に発生している重症熱性血小板 減少症候群（SFTS）のような地域性のあるダ二関連 感染が病歴と身体所見で疑われる場合，事前に搬送 予定の医療機関に情報を伝達する ${ }^{62) 。 ~}$

項目 35. 当該感染症について, 病院前救護活動を行 う職員に対して行う感染防止対策の指示内容が用意 されている。

<カテゴリー＞

特定

<解説 >

当該感染症は何かを想定することから対応は始ま る。当該感染症に対する適切な感染防止の効果的な 手段は，感染経路を遮断することである9 。これを 感染経路別予防策と言う。しかし, 感染経路別予防 策は傷病者の感染症が判明している場合に適応する 対策である。病院前救護活動を行う職員は，対応す る傷病者が感染症かどうかも分からない状況で接触 せざるを得ない。よって，現実的には標準予防策か ら対策を始める。標準予防策は，対応する傷病者の 汗を除く唾液・鼻汁・喀痰・尿・便・腹水・胸水な ど全ての湿性体液には感染性があるものとして取り 扱う基本的な感染対策であり，感染経路別予防策は それに追加して対応する9。標準予防策を適応しつ つ，下痢・嘔吐，発疹，発熱，咳，排膿等は経験的
な経路別予防策が必要である。具体的には，呼吸器 疾患が予想される場合は飛沫と空気感染予防策を追 加し, 消化器疾患では接触・飛沫感染予防策を追加 して傷病者を扱う。その際，病院前救護活動を行う 職員に対する適切な感染対策の指示内容としては, 季節性に，冬季ではインフルエンザ，秋から冬季で はノロウイルス主体とした感染性胃腸炎を想定した 具体的な予防策のプロトコールを四半期ごとに用意 する。「救急隊の感染防止対策マニュアル（Ver. 1.0)」63)を参照。

項目 36. 病院前救護活動を行う職員が，結核，麻疹， 水痘などが確定もしくは強く疑われる情報を得た場 合は，病院前救護活動を行う職員に対し適切な感染 防止対策を指示している。

<カテゴリー>

四半期（常時）

<解説>

病院前救護活動を行う職員が，結核，麻疹，水痘 などが確定もしくは強く疑われる情報を得た場合， 空気感染予防策を講じる。結核侵淫地域での出動で は傷病者接触前の情報収集が必須で，(1) 2 週間以上 の長引く咳を訴える，(2) 1 年以内に結核菌塗抹陽 性患者と接触した，(3)他疾患の治療中に，咳，発熱 が出現し，治りにくい，(4)抗菌薬治療されているが 反応の悪い不明熱等 ${ }^{64)}$ が該当する場合，「結核傷 病者の搬送」65)に従った対応をして搬送時感染対策 とする。具体的には，(1)傷病者にはサージカルマス クを着用してもらう（酸素投与時のフェイスマスク でもよい)，(2)換気扇を回す，または空を開けて救 急車内の換気をよくする，(3)病院前救護活動を行う 職員はN95 マスクを着用する（同乗する関係者に も着用してもらう)，(4)資器材については適切な方 法で洗浄と消毒を実施する，(5)污染した傷病者への 対応環境，救急車内での大型機器表面などは，血液 等目に見える大きな污染物が付着している場合は, これを清拭除去したうえで，適切な消毒薬を用いて 清拭消毒する，とある。麻疹，水痘に関しては，疑 
表 3. 職業感染対策

\section{(1)針刺し防止策}

1) 安全装置付きの静脈留置針を使用する。

2) 専用容器は静脈路確保後, 手の届く場所に置く。

3）静脈留置針は，穿刺した病院前救護活動を行う職員が責任を持って専用容器に捨てる。

4) 留置針を手渡ししたり，一時的にストレッチャーの上や床等に置かない。

5) リキャップはしない。

6) ゴーグルやフェイスシールドで眼を，サージカルマスクで口・鼻への曝露を防止する。

(2) 発生時の処置

1) 流水で洗い流す。口で吸ってはいけない。

2) 石鹸と大量の流水でしっかり洗う。

3）血液・体液が口に入ったら，うがいをする。

4) 血液・体液が眼に入ったら，流水で眼洗する。

5) 血液・体液が創傷部に触れたら, 流水で洗い流す。

(3)発生後の対応

1) 傷病者の B・C 型肝炎, HIV 感染症情報を収集する。

2) 曝露した病院前救護活動を行う職員の B · C 型肝炎, HIV 感染症, 肝機能等を検査する。

3） 1 ， 2 に基づき，病院前救護活動を行う職員への抗 $\mathrm{B}$ 型肝炎ヒト免疫グロブリン接種等の緊急処置の必 要性と, 定期的な観察で良いか，およびその後の検査スケジュールを決める。

われる傷病者と接触する病院前救護活動を行う職員 は，免疫を有する抗体陽性者あるいはワクチン 2 回 接種している者を優先的にするべきである。感染対 策としては，麻疹，水痘は感染傷病者の鼻汁，唾液 などの湿性体液に含まれており，飛沫を吸い込んで 感染する場合が多いため, 最低限対応する救急隊は サージカルマスクの着用が重要である。結核と異な り，麻疹，水痘に免疫を有している者が対応するの が基本と考える。病院前救護活動を行う職員は医療 機関を受診し，麻疹，水痘，風疹，ムンプス，B 型 肝炎等の抗体価を調べ，必要に応じてワクチン接種 することが望ましい。

項目 37. 診断に基づき，病院前救護活動を行う職員 に対し職業感染対策，表面消毒，環境回復について 助言を行っている。

<カテゴリー＞

臨時

$<$ 解説 $>$

救急救命士による薬剂投与や心停止前の輸液等の 処置範囲の拡大に伴い, 病院前救護活動を行う職員
に対する職業感染対策，表面消毒，環境回復は重要

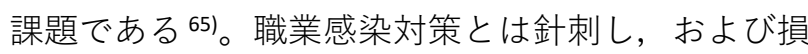
傷皮膚・粘膜（特に目）への血液・体液曝露時の対 策である。対策は，(1)防止策，(2)発生時の処置，(3) 発生後の対応に分かれる（表 3 参照）。この対応に は医療機関との連携が必要となる。新興感染症につ いての機器・器具・環境の表面消毒・滅菌, 環境回 復に関しては，「感染症の予防及び感染症の患者に 対する医療に関する法律」通称「感染症法」11)に基 づいて対応するのが現実的である。一般原則とし て, 感染症の病原体で污染された機器・器具・環境 の表面消毒・滅菌は，適切かつ迅速に行い，污染拡 散を防止する。(1)病院前救護活動を行う職員の手 袋，帽子，感染防止衣，傷病者に直接使用する救急 資器材は，可能なかぎり使い捨て製品を使用する。 (2)使用後は，専用の感染性廃棄物用容器に密閉する か，あるいはプラスチック袋に二重に密閉したうえ で，外袋表面を清拭消毒して傷病者と接触している 現場より持ち出し，焼却処理する。(3)污染した再利 用器具は, Spaulding の分類（項目 31 表 2 参照）に 準拠し, 用手洗浄後, 器具の使用目的に適した消毒 
表 4. 滅菌, 消毒, 洗浄の定義と対象資器材

\begin{tabular}{|c|c|c|}
\hline 分類 & 定義 & 救急資器材 \\
\hline 滅菌 & 通常, 無菌の組織や血管に挿入されるもの & $\begin{array}{l}\text { 静脈留置針 } \\
\text { 気管チューブ }\end{array}$ \\
\hline 消毒 & 損傷のない粘膜や創のある皮膚に接触するもの & 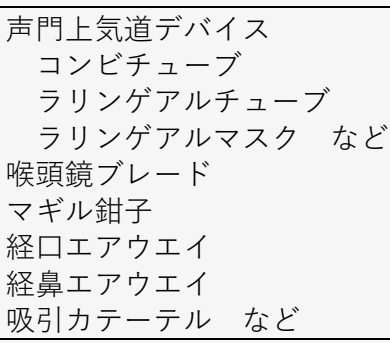 \\
\hline 洗浄 & 損傷のない皮膚に接触するもの & $\begin{array}{l}\text { 聴診器 } \\
\text { 血圧計のカフ } \\
\text { 酸素マスク } \\
\text { 体温計 } \\
\text { バッグバルブマスク } \\
\text { 頸椎カラー } \\
\text { 副子 } \\
\text { ターポリン担架 } \\
\text { バッグボードなど }\end{array}$ \\
\hline
\end{tabular}

(安田康晴 : 救急現場活動シリーズ 2。感染防止対策と個人防護。へるす出版，東京，2014，p23 を改編）

薬による浸漬消毒を行う（表 4 参照）。(4)そのうえ で，滅菌などの必要な処理を行った後，再使用に供 する。洗浄後消毒薬浸漬を行う。リネンは浸漬消毒 しないので，部分的な污染（血液）に限定される。 (5)污染した傷病者への対応環境，救急車内での大型 機器表面などは, 血液等目に見える大きな污染物が 付着している場合は，これを清拭除去したうえで， 適切な消毒薬を用いて清拭消毒する。清拭消毒前 に，污染微生物量を極力減少させておくことが清拭 消毒の効果を高めることになる。消毒薬処理は, 滅 菌処理と異なり，対象とする微生物の範囲が限られ ている。抗菌スペクトルからはみ出る微生物が必ず 存在し, 条件が揃えば消毒薬溶液中で生存増殖する 微生物もある。よって, 対象微生物を考慮した適切 な消毒薬の選択が必要となる。消毒薬の選択は収容 する医療機関の感染防止マニュアルを参考にすると 良い。

\section{項目 38. 診断に基づき，病院前救護活動を行う職員 に対し職業感染対策，表面消毒，環境回復について の助言内容が用意されている。}

<カテゴリー＞

特定

$<$ 解説 >

病院前救護活動を行う職員に対する職業感染対策 は, 病院前救護活動を行う職員の手袋, 帽子, 感染 防止衣等の個人防護具（PPE）類，傷病者に直接使 用する救急資器材をできる限り使い捨てにできるよ うに事前準備する。専用の感染性廃棄物用容器は満 杯になっていないか事前確認し，満杯の場合は内容 破棄し表面消毒を徹底する。消毒用アルコール等消 毒薬は使用期限の確認と補充をし，血液や体液污染 したリネン類はないか確認する。表面消毒，環境回 復対策の準備は「感染症法」に指定された感染が疑 われる傷病者と接触・対応し, 搬送する場合, 分類 ごとに定められた方法を補足する ${ }^{65)}$ (表 5 参照）。 グルタラールは，本来ホルムアルデヒドガス曝露防 止の点で浸漬での消毒は使用しないが, 病院前で は，消毒を徹底するために密閉空間でないところで の実施を検討する。一般原則として，感染症の病原 体で污染された機器・器具・環境の表面消毒・滅菌 は, 適切かつ迅速に行い, 污染拡散を防止するが, 
表 5 感染症法上の分類と消毒方法

\begin{tabular}{|c|c|c|c|}
\hline & 病原体 & 消毒のポイント & 消毒方法 \\
\hline \multirow[t]{3}{*}{ 一類感染症 } & $\begin{array}{l}\text { エボラ出血熱, クリミア・コンゴ } \\
\text { 出血熱, マールブルグ病, ラッサ } \\
\text { 熱, 南米出血熱 }\end{array}$ & $\begin{array}{l}\text { 厳重な消毒が必要である傷 } \\
\text { 病者の血液・分泌物・排泄 } \\
\text { 物, およびこれらの付着し } \\
\text { た可能性のある箇所を消毒 } \\
\text { する。 }\end{array}$ & 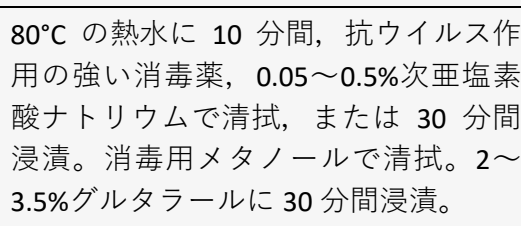 \\
\hline & ペスト & $\begin{array}{l}\text { 肺ペストは飛沫感染である } \\
\text { が，傷病者に用いた機器や } \\
\text { 傷病者環境の消毒を行う。 }\end{array}$ & 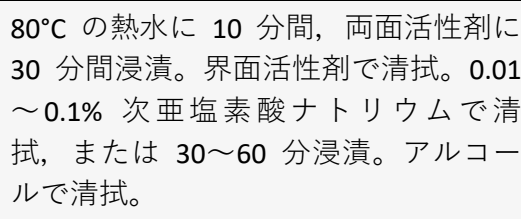 \\
\hline & 痘瘡 & 傷病者環境の消毒を行う。 & エボラ出血熱と同様。 \\
\hline \multirow[t]{4}{*}{ 二類感染症 } & $\begin{array}{l}\text { 急性灰白髄炎 (ポリオ), 重症急性 } \\
\text { 呼吸器症候群 (SARS) }\end{array}$ & $\begin{array}{l}\text { 傷病者の糞便で污染された } \\
\text { 可能性のある箇所を消毒す } \\
\text { る。傷病者環境の消毒を行 } \\
\text { う。 }\end{array}$ & 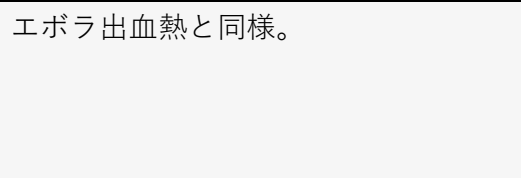 \\
\hline & $\begin{array}{l}\text { 中東呼吸器症候群（病原体がベー } \\
\text { タコロナウイルス属MERSコロナウ } \\
\text { イルスであるものに限る。）, 鳥イ } \\
\text { ンフルエンザ (H5N1とH7N9） }\end{array}$ & $\begin{array}{l}\text { 飛沫感染および接触感染と } \\
\text { 考えられており, 傷病者に } \\
\text { 用いた機器や傷病者環境の } \\
\text { 消毒を行う。 }\end{array}$ & エボラ出血熱と同様。 \\
\hline & ジフテリア & $\begin{array}{l}\text { 皮膚ジフテリアなどを除き } \\
\text { 飛沫感染であるが, 傷病者 } \\
\text { に用いた機器や傷病者環境 } \\
\text { を消毒する。 }\end{array}$ & ペストと同様。 \\
\hline & 結核 & $\begin{array}{l}\text { 空気感染であるが, 傷病者 } \\
\text { に用いた機器や傷病者環境 } \\
\text { を消毒する。 }\end{array}$ & $\begin{array}{l}\text { 救急車内は換気。車内床等は通常の洗 } \\
\text { 浄・消毒。毛布等は日光消毒し洗浄。 }\end{array}$ \\
\hline \multirow[t]{2}{*}{ 三類感染症 } & $\begin{array}{l}\text { コレラ, 細菌性赤痢, 腸管出血性 } \\
\text { 大腸菌感染症 }\end{array}$ & $\begin{array}{l}\text { 傷病者の糞便で污染された } \\
\text { 可能性のある箇所を消毒す } \\
\text { る。消毒薬の散布や噴霧は } \\
\text { しない。 }\end{array}$ & ペストと同様。 \\
\hline & 腸チフス, パラチフス & $\begin{array}{l}\text { 傷病者の糞便・尿・血液で } \\
\text { 污染された可能性のある箇 } \\
\text { 所を消毒する。 }\end{array}$ & ペストと同様。 \\
\hline 四類感染症 & $\begin{array}{l}\text { E 型肝炎, ウエストナイル熱（ウ } \\
\text { エストナイル脳炎を含む。， A 型 } \\
\text { 肝炎, エキノコックス症, 黄熱, } \\
\text { オウム病, オムスク出血熱, 回帰 } \\
\text { 熱, キャサヌル森林病, } \mathrm{Q} \text { 熱, 狂 } \\
\text { 犬病, コクシジオイデス症, サル } \\
\text { 痘, 重症熱性血小板減少症候群 } \\
\text { (病原体がフレボウイルス属SFTS } \\
\text { ウイルスであるものに限る。), 腎 } \\
\text { 症候性出血熱, 西部ウマ脳炎, ダ } \\
\text { 二媒介脳炎, 炭疽, チクングニア } \\
\text { 熱, つつが虫病, デング熱, 東部ウ } \\
\text { マ脳炎, 鳥インフルエンザ (H5N1 } \\
\text { 及びH7N9を除く。), ニバウイルス } \\
\text { 感染症, 日本紅斑熱, 日本脳炎, }\end{array}$ & $\begin{array}{l}\text { 芽胞形成菌以外, 傷病者に } \\
\text { 用いた機器や傷病者環境を } \\
\text { 消毒する。環境消毒は, 污 } \\
\text { 染局所に対して消毒の必要 } \\
\text { がある場合に行う。つつが } \\
\text { 虫病においては予防策はな } \\
\text { し。芽胞形成菌芽胞には高 } \\
\text { 水準消毒薬の長時間接触が } \\
\text { 必要である。炭疽菌の污染 } \\
\text { 物は滅菌もしくは焼却が基 } \\
\text { 本である。作業者は防護服 } \\
\text { を着用して作業にあたらな的 } \\
\text { ければならない。 }\end{array}$ & $\begin{array}{l}\text { 芽胞形成菌以外の消毒法 } \\
\text { (1)煮沸（98 }{ }^{\circ} \mathrm{C} \text { 以上） } 15 \sim 20 \text { 分間 } \\
\text { (2) } 2 \% \text { グルタラール } \\
\text { (3) } 0.05 \sim 0.5 \% \text { 次亜塩素酸ナトリウム } \\
\text { (4) } 76.9 \sim 81.4 \% \text { 消毒用エタノール } \\
\text { 芽胞形成菌の消毒法 } \\
\text { 消毒前に, 洗浄を十分に行い, 付着し } \\
\text { ている芽胞の数を減らす。グルタラー } \\
\text { ルに } 3 \text { 時間以上の浸漬。 }\end{array}$ \\
\hline
\end{tabular}


表 5. 感染症法上の分類と消毒方法（続き）

\begin{tabular}{|c|c|c|c|}
\hline & 病原体 & 消毒のポイント & 消毒方法 \\
\hline 四類感染症 & $\begin{array}{l}\text { ハンタウイルス肺症候群, Bウイ } \\
\text { ルス病, 鼻疽, ブルセラ症, ベネ } \\
\text { ズェラウマ脳炎, ヘンドラウイル } \\
\text { ス感染症, 発しんチフス, ボッリ } \\
\text { ヌス症, マラリア, 野兔病, ライ } \\
\text { ム病, リッサウイルス感染症, リ } \\
\text { フトバレー熱, 類鼻疽, レジオネ } \\
\text { ラ症, レプトスピラ症, ロッキー } \\
\text { 山紅斑熱 }\end{array}$ & & \\
\hline $\begin{array}{l}\text { 五類感染症 } \\
\text { (全数) }\end{array}$ & 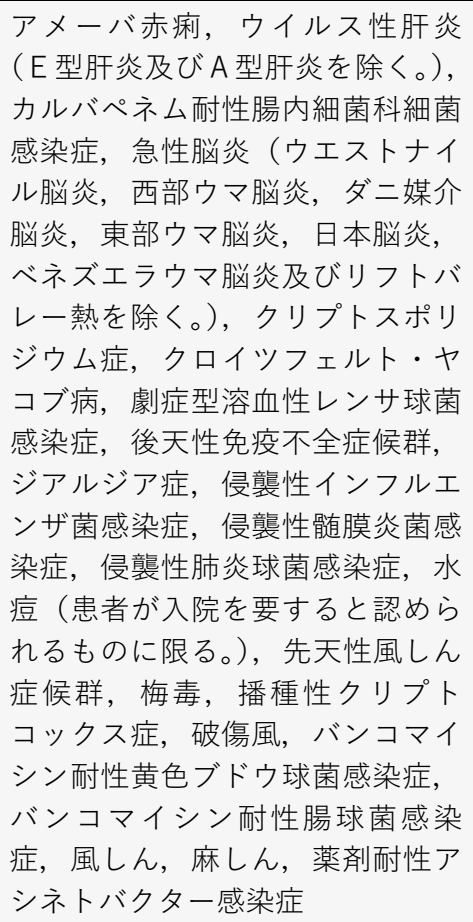 & $\begin{array}{l}\text { 標準予防策に準ずる。 } \\
\text { 疾患特有の感染経路を認識 } \\
\text { して対応する。 } \\
\text { 感染経路別に有効な消毒を } \\
\text { 行う。 } \\
\text { (1) 空気感染 } \\
\text { 適切な空調, 換気 } \\
\text { (2) 飛沫感染 } \\
\text { 環境清掃の徹底 } \\
\text { (3) 接触感染 } \\
\text { 資器材やドアノブなど, } \\
\text { 傷病者や救急隊員が触れ } \\
\text { た場所の消毒・清掃 }\end{array}$ & 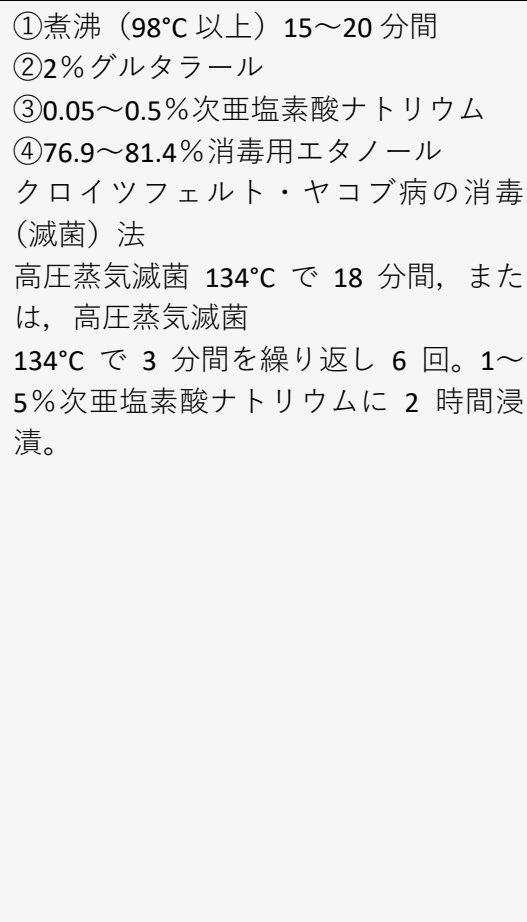 \\
\hline
\end{tabular}

（安田康晴：救急現場活動シリーズ 2. 感染防止対策と個人防護。へるす出版, 東京, 2014, p42-3 より改編）

感染症法は随時改訂されるので適宜情報のアップ

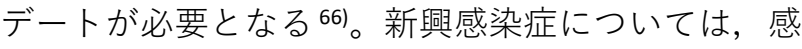
染症法に基づく対応となるが, 中東呼吸器症候群に 関しては中東に旅行もしくは居住してラクダから曝 露した可能性のある傷病者は未だ絶えないことと, 鳥インフルエンザもアジア圈中心に散発している現 状は常にインターネット等で情報を更新し，事前収 集しておく61,67)。補足情報として，新興感染症に関 しては感染症法が基本であるが，新型インフルエン ザ及び全国的かつ急速な瞢延のおそれがある新感染 症に対する対策の強化を図り，「新型インフルエン ザ等対策特別措置法」, 通称「特措法」が 2012 年 4
月 27 日制定，同年 5 月 11 日に公布され，地方自治 体主導で運用・体制整備が進められている。全国の 医療機関では受入要請として医療需要の増大や職員 の欠勤が生じることを想定した「診療継続計画」, 通称「BCP」を作成・整備し, 行政と連携している 現状があるが詳細は別紙に譲る ${ }^{48)}$ 。病院前の対応も 予想されるので，今後検討を要する要件の一つであ る。

項目 39. 結核，麻疹，水痘などが確定もしくは強く 疑われる場合は，診断に基づき，病院前救護活動を 行う職員に対し職業感染対策，適切な清掃，表面清 
拭・消毒，環境回復などについて助言を行っている。

<カテゴリー＞

四半期（常時）

<解説 $>$

結核，麻疹，水痘などが確定もしくは強く疑われ る場合は，診断に基づき，病院前救護活動を行う職 員に対し職業感染対策，適切な清掃，表面清拭・消 毒，環境回復などについては助言を行っている。結 核，麻疹に関しては空気感染対策なので，搬送後， 傷病者に用いた機器や傷病者環境を消毒する程度で 良い。搬送後の指示としては，都市部で結核侵淫地 域では結核対策が重要で，救急搬送後は情報の収集 が必須となる。N95 マスク未着用で濃厚接触した病 院前救護活動を行う職員がいた場合，「接触者検 診」の適応となるので，対応が厳密になってくる。 なお，2000 年 5 月より，新結核菌検査指針では結 核菌の排菌ガフキー号数での表示から $1+\sim 3+$ の簡 便な記載法に改められた ${ }^{68)}$ 。四半期定期的な全隊員 の健康状態のチェックは重要で， 2 週間以上の長引 く咳をする隊員はいないかの確認作業は必要であ る。さらに，無症候でも結核は潜在的に進行する疾 患なので，年 1 回は最低限病院前救護活動を行う全 職員の胸部レントゲン撮影での健康チェックが勧め られる ${ }^{63)}$

\section{(5) 病院間搬送}

項目 40. 必要に応じ患者の個人情報に配慮した上で, 前医に感染対策について適切な助言を行っている。

<カテゴリー>

臨時

<解説 >

必要に応じ, 特に新興感染症において, 感染力が 強い, あるいは病原性の高いものについては個人情 報に配慮のうえ，適切な情報提供を前医へ，感染対 策について適切な助言を行う。国内であれば，重症 熱性血小板減少症候群（SFTS）のような西日本を中 心に発生している地域性のあるダ二関連感染 ${ }^{62)}$, 海
外から侵入してくる可能性のある感染性疾患では中 東呼吸器症候群 61), 高病原性鳥インフルェンザ （H5N1 と H7N9）を始め，日本では稀もしくは経験 のない新興・再興感染症の最新情報は公的には厚生 労働省検疫所（FORTH）ホームページ等で開示され

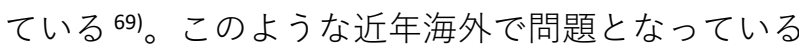
新興感染症の国内侵入の脅威を受け，新型インフル エンザ及び全国的かつ急速な蔓延のおそれがある新 感染症に対する対策の強化を図り，「新型インフル エンザ等対策特別措置法」, 通称「特措法」が 2012 年 4 月 27 日制定，同年 5 月 11 日に公布され，地方 自治体主導で運用・体制整備が進められている 70)。この特措法が運用されるような新興感染症の国 内侵入時，およびパンデミック対応では，地方自治 体/保健所などの行政の指示のもとで感染対策が講 じられる。感染が疑われる患者への対応において, 病院間搬送での前医への指示及びフィードバックは 個々で対応すべきことは「感染症の予防及び感染症 の患者に対する医療に関する法律」, 通称「感染症 法」の適応で済むが，特措法が運用される事態では 地方自治体/保健所などの行政の指示のもとで対応 することが予想される。新興感染症や特措法対応は 行政機関で搬送のプロトコール等があるので，それ に完全準拠する必要があるからである。搬送患者の 最終的な感染症診断の情報を行政から適切に入手 し，報告を受けることも 2 次感染防止の視点から必 要と考える。

項目 41. 前医の情報から，適切な搬送時期，搬送方 法について指示を行っている。

<カテゴリー＞

臨時

項目 42. 病院から外部へ患者搬送を行う場合には, 受け入れ施設や搬送車両に対して感染制御に関する 情報を適切に提供し指導している。

<カテゴリー>

特定及び臨時 
$<$ 解説 $>$

感染が疑われる患者への対応，病院間搬送にお いて，転送先への情報提供，対策の指示も概念的 には，(1)市中で季節性に蔓延している感染性疾患 と, (2)国内・海外から侵入してくる可能性のある 感染性疾患, 特に新興感染症において, 感染力が 強い，あるいは病原性の高いものについては個人 情報に配慮のうえ, 前医の情報から適切な搬送時 期，搬送方法について行う。(1)に関しては，夏か ら秋にかけて RS ウイルス感染, 秋から冬にかけて 感染性胃腸炎（特にノロウイルス），冬から春にか けてインフルエンザ等が該当する。(2)に関して は，国内であれば，重症熱性血小板減少症候群 （SFTS）のような西日本を中心に発生している地域 性のあるダ二関連感染 ${ }^{62)}$, 海外から侵入してくる 可能性のある感染性疾患では中東呼吸器症候群 61), 高病原性鳥インフルエンザ（H5N1 と H7N9）を始 め, 「新型インフルエンザ等対策特別措置法」, 通 称「特措法」が運用されるような新興感染症の国 内侵入時, およびパンデミック対応では, 地方自 治体/保健所などの行政の指示に従う。病院間搬送 で前医への指示及びフィードバックは個々で対応 すべき感染が疑われる患者への通常の対応におい ては，「感染症の予防及び感染症の患者に対する 医療に関する法律」, 通称「感染症法」の適応で済 むが，特措法が運用される事態では地方自治体/保 健所などの行政の指示のもとで対応することにな る。転送の可否及び搬送方法は，基本的には医療 機関同士の話し合いで決まるが，病原微生物が特 定できず，新興感染症，特に海外発生の新型イン フルエンザ等感染症や, 新感染症が疑われる場合 は，「都道府県知事は，前条の規定により入院す る新感染症の所見がある者を当該入院に係る病院 に移送しなければならない。」（感染症法 第四十 七条） ${ }^{71)}$ に則り，地方自治体/保健所に連絡し，指 示を仰ぐ。自院から患者を送り出す場合に，受け 入れ病院への情報提供や搬送車両に対する感染制 御に関する情報を提供することは重要である。行
政が指定する車両やアイソレーターを要する場合 があるからである。

\section{3. モニタリング}

\section{(1) 機器，環境など}

項目 43. 特殊診察室を設置し陰圧室の陰圧（差圧）, フィルター管理を定期的に確認する体制がある。

<カテゴリー>

年 1 回

$<$ 解説 $>$

救急外来部門には，診断を受ける前の感染症患者 が受診する。空気感染，飛沫感染，接触感染を起こ す可能性のある微生物の感染症が疑われる患者 （例，下痢，発熱を伴う呼吸器症状，発熱を伴う発 疹など）は，個室で診察することが望ましい7,72)。 なかでも空気感染を起こす微生物が医療従事者や患 者に二次感染することを予防するためには，陰圧個

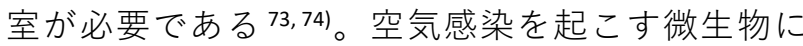
は, 結核, 水痘帯状疮疹ウイルス, 麻疹ウイルス, 天然痘ウイルスがある。また，CDC ガイドラインで は，ウイルス性出血熱（エボラ出血熱，マールブル グ病，ラッサ熱，クリミア・コンゴ出血熱）に関し て，医療機関内における空気を介する感染の報告は ないものの，慎重を期して（前室のある）陰圧個室

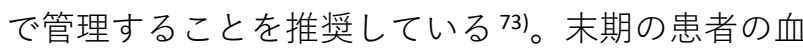
液, 吐物，液状の便，気道分泌物などがエアロゾル 化して感染を媒介する可能性があり，このリスクを

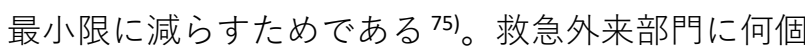
の陰圧個室が必要かを受診する患者や地域の実情を 踏まえて検討する ${ }^{73)}$ 。また，現在救急外来部門に陰 圧個室がない場合は，改築や移転の際に陰圧個室の 設置を検討すべきである。ウイルス性出血熱に関わ らず，空気感染を予防するための陰圧個室には前室 があることが望ましい73)。前室がない場合は HEPA （high efficiency particulate air）フィルター付空気清 浄機を陰圧個室内に設置すれば空気中の粒子を減ら 
すことができる。ただし，効果は限定的であるため HEPA フィルター付空気清浄機のみでは，陰圧個室 としての代替は難しい。最低限，年に 1 回は陰圧室 の差圧が適切であるか，フィルターが適切に使用お よび管理されているかを確認する。差圧などの推奨 は，CDC ガイドラインに掲載がある ${ }^{73)}$ 。

\section{4. 構造，ハードウェアの感染リスクの管理}

\section{(1) トイレ}

項目 44. 救急外来内に複数のトイレがある。

項目 45. 個室（隔離用診療室）内，あるいは近接し た場所にトイレがある。

項目 46. トイレに手洗い設備が備えられている。 項目 47. トイレの床は清掃しやすい構造である。

<カテゴリー>

年 1 回

<解説 $>$

病院內において，トイレは病原体により污染しや すいので，その管理は重要である。便器表面だけで はなくその周囲の物品や床，壁なども，頻繁に清

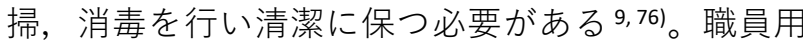
と患者用トイレは別のものにすることが望ましい。 特に救急外来部門においては，ノロウイルスなど感 染性胃腸炎の流行期に注意が必要である。腸管由来 微生物による感染が疑われる，もしくは診断を受け た患者は，他者への感染を防ぐために，それ以外の 患者が使うトイレとは別のトイレを使用するように するべきである9 。これをできるようにするため に，救急外来部門内に患者用トイレは複数設置する ことが望ましい。便器やその周辺が便などにより污 染した場合は，清掃や消毒が完了するまでは，一時 的にトイレ全体の使用を中止する。トイレ付きの個 室を使用して，一患者のみが使うようにできるのが より望ましい9)。個室が使用できない場合は，一患 者に対して一つの移動式トイレを使用して，便器だ
けではなく便が付着する可能性のある周囲の物品や 床，壁なども十分に清掃，消毒することが重要であ る 9 , 77,78)。このとき，感染が流行している微生物に 応じて，感受性がある適切な薬品を用いる。トイレ の洗面台は自動水栓が望ましい。トイレの床は清掃 しやすい構造が望ましい。便器が壁排水式であれ ば，床の清掃が行いやすい。病院や救急外来部門の 新築および改築時には，これらを採用するべきであ る。

\section{(2) 待合室}

項目 48. 感染症の流行期，あるいは必要時には，待 合室，診察室をコホートしている。

<カテゴリー>

四半期（常時）及び臨時

$<$ 解説 $>$

感染経路別予防策が必要な患者の長時間の滞在 は，待合室や診察室を介しての他の患者・付き添い 家族への伝播リスクとなる。そのため，感染経路別 予防策が必要な患者（疑い含む）の来院時は，待合 室や診察室を別にし，他の患者・付き添い家族との 接触をできるだけ避けるようにする52)。

インフルエンザなどの流行期には，有症状者を早 期に検出するためのポスター掲示や，受付時に有症 状者を確認するようトリアージ体制を整備する。有 症状者は待合室を別にすることが望ましいが，不可 能な場合は最低 $1 \mathrm{~m}$ の距離をとって座るなどの対応 を行う 79)。また，待合室の椅子は患者間の飛沫の曝 露を防止するため, 向かい合わせの配置は避ける。 待合室の広さなど設備面で困難なこともあるが，救 急外来における集団感染をできるだけ防ぐような配 慮が必要である。

項目 49. 受付にサージカルマスク, 手指消毒薬, ティシュペーパーが常備されており，足踏み式のゴ ミ箱へただちに，適切に廃棄できるよう運用されて いる。 
環境感染誌 Vol. 35 no. 3, 2020

<カテゴリー>

四半期（常時）

$<$ 解説 $>$

救急外来に来院する患者には感染性疾患を有して いるものも多いが，来院時には多くは未検査であ り，すべての人に対して標準予防策を適切に実施す ることが重要である。手指衛生は感染対策の基本で あり，必要な時にすぐに実施できるよう環境を整え ておく必要がある52)。受付は来院患者が必ず立ち寄 る場所であり，患者も含め，誰もが必要な時に簡便 に手指衛生が実施できるように手指消毒剂を設置し ておくことが必要である。

受付には発熱や咳などの呼吸器症状があっても, 微生物の拡散防止のためにサージカルマスクを着用 せずに来院する患者も少なくない。呼吸器症状があ る患者には受付でサージカルマスクをつけてもら う52)。また，待合室にいる間も咳や痰などが発生す る可能性もある。そのような患者に対応するため, 受付にはティッシュペーパーを常備し，使用後はす ぐに廃棄できるようゴミ箱を設置することが必要で ある。ゴミ箱の蓋を手で開けるタイプの場合，污染 した手で触ることで污染が拡がる可能性あるので, 足踏み式のごみ箱を設置する7)。また，ティッシュ ペーパーを廃棄した後は必ず手指衛生を行わなけれ ばならない。手指が污染した場合は石鹸と流水によ る手指衛生，眼に見える污染がない場合は手指消毒 剂による手指衛生を速やかに行う。石鹸と流水によ る手指衛生を行う場合，手洗い設備に移動する間に 污染を広げないよう，共有部分を触らないように注 意することも必要である。

\section{項目 50. 建物外にインターホン, 電話等, 院内の職 員が応答できる設備がある。}

<カテゴリー>

年 1 回

$<$ 解説 $>$

新型インフルエンザなど新興・再興感染症の罹患 を疑う患者は，直接診察室に入室すると他の患者や
医療従事者が曝露し，感染の拡大につながるリスク が高くなる。他の患者や医療従事者の曝露をできる だけ低減させるため, 通常の診察エリアからできる だけ離れた場所で診察することが必要となる ${ }^{52) 。 ~}$

よって新型インフルエンザ等が海外で発生し, 病 原性が強い恐れがある場合，新型インフルエンザ等 を疑う患者の診療は，受入れ体制を整え対応する必 要がある。診療の受け入れには，他の患者と交差し ないような導線を確保し，ガウン・手袋・N95 マス ク・ゴーグルなど適切な防護用具を用いて対応する ことが必要である ${ }^{521 。}$

そのためにもインターホンや電話など，建物外か ら患者が直接職員と連絡が取れ，来院したことや症 状などを伝えることができる設備があることが望ま しい。またこのような設備や体制をとっていること を広報することも重要である。

\section{項目 51. 患者待合室に手指衛生を行うことができる 設備がある。}

<カテゴリー>

四半期（常時）

$<$ 解説 $>$

救急外来には感染性疾患の患者も多く来院し，患 者の症状によっては，環境が血液や体液，排泄物な どで污染される可能性もある。感染性疾患の患者や 付き添い家族の手指は污染されている可能性が高 い。手指衛生は感染対策の基本であり，医療従事者 だけでなく患者にも手指衛生の遵守が望まれる。手 指衛生の遵守向上には手指衛生が実施できる環境を 整えることが重要である。

受付や待合室に手指消毒剂を設置することは容易 に可能であるが，血液や体液などの有機物で污染さ れた場合は，石鹸と流水による手指衛生を行うこと が必要であり，手洗いシンクの設備が必要となる。 手洗いシンクをすぐに設けることは困難かもしれな いが，新築や改修など設備の見直しが可能な機会に は，患者待合室に手洗い設備を設けることが推奨さ れる。また，手洗いシンクの管理，清掃も重要であ 
る。

項目 52. イスは湿式清掃可能な素材である。

<カテゴリー＞

特定

$<$ 解説 $>$

病院の椅子を介した感染拡大を示す報告はない が，病院の環境清掃の基本は湿式清掃であり，日常 的に環境用洗浄剂で湿式清掃が可能な素材を使用す べきである。特に救急外来では, 出血や嘔吐など, 環境を污染する状況が発生するリスクが高く，待合 室の椅子は清掃しやすい素材を使用すべきである。

また有機物で污染した場合は，次亜塩素酸ナトリ ウムやアルコールなどの消毒剂を使用することもあ るため, これらの消毒剤にも耐えうる素材のものが 望ましい。

項目 53. 待合室の近くにトイレがあり，動線が明確 にされている。

<カテゴリー＞

特定

<解説 >

救急外来には感染性疾患で下痢や嘔吐などの症状 を有する患者が来院することも多く，患者が急にト イレに行く状況になる可能性も高い。よって, 待合 室や診察室の近くにトイレがあることが望ましい。 また，付き添い家族に家族内感染があった場合，付 き添い家族に急な症状が出現する可能性もあり，そ の意味でも待合室の近くにトイレがあることが望ま しい。

トイレの場所はすぐにわかるように表示し，下痢 や嘔吐などの症状を有する患者には，受付時にトイ レの場所を案内することや診察を待つ場所をトイレ の近くに案内するなど配慮する。

感染性疾患が疑われる患者や家族の急な症状によ る環境の污染や，使用後の環境污染の可能性を考え ると，施設の大きさにもよるが，複数のトイレがあ り他の患者・付き添い家族と使用するトイレを分け
ることが望ましい。新築・大規模改修の際には検討 が望まれる。

\section{(3) 診察区域}

\section{項目 54. 特殊診察室には個人防護具（PPE）などを 備えた前室がある。}

<カテゴリー>

年 1 回

$<$ 解説 $>$

特殊診察室を使用する目的には，空気予防策のた め陰圧室として機能する場合，差圧を発生させて室 内気流を適切にコントロールする場合と，接触予防 策のうえでは物理的に隔離されていることを確認 し，感染対策のコンプライアンスを維持し間接接触 感染のリスクを低減させるために，標準予防策に付 加して行うものである。空気予防策の適用を除き， 専用隔離室が使用できない場合には，患者が物理的 に隔離されていることを確認するための空間確保 [>3 フィート（約 $1 \mathrm{~m} ）$ の距離など］や，濃厚接触 を最小限にするためにベッド間にあるプライバシー カーテンを使用することが推奨される 9,73,74)。

項目 55. 診察室，前室のドアは引き戸になっている。

<カテゴリー >

臨時

$<$ 解説 $>$

新規の前室の設置は困難な場合は引き戸にするこ とも推奨される。引き戸は扉を開く際にドア内外の 圧差が保たれ，かつ外から内側への気流が維持され やすいため推奨されている ${ }^{80,81)}$ 。過去に結核予防会 複十字病院の医師による基礎実験文献を参考にして いるが，結核患者収容モデル事業（国庫補助事業） の実施要項 ${ }^{82)}$ においても，特に陰圧室の出入り の扉は，空気の循環にできるだけ影響を与えないよ う引き戸とすることが求められている。施設改善が 可能なタイミングを加味し，対応することが望まし いことから，隔離室として指定する場合や新設時の 
確認（臨時）でよい。

項目 56. 行政機関に提出が必要な検体，および採取 時の感染制御法について周知されている。

<カテゴリー＞

臨時

$<$ 解説 $>$

「感染症の予防及び感染症の患者に対する医療に 関する法律」第 16 条の 3 , 第 26 条の 4, 第 27 条, 「感染症の予防及び感染症の患者に対する医療に関 する法律施行規則」第 10 条, 第 31 条及び「感染症 法に基づく特定病原体等の管理規制について（厚生 労働省）」において遵守事項等管理規定が定められ ている。ハード面の管理や法的な取り交しが主だっ た内容である。検体採取時に想定される疾患や微生 物に応じた感染経路別予防策を行う必要がある。採 取環境管理（隔離室または陰圧室等）と個人防護具 （PPE）の正しい着脱。採取検体の保管及び採取環境 の環境管理（換気や環境消毒清掃）について明文化 し周知される必要がある。

\section{(4) 新規に採用される医療機器・医療材料}

項目 57. 新規の医療機器, 医療材料が導入される際 には，感染制御の專門家の確認が行われ，現場に対 し適切な助言が行われている。

<カテゴリー>

特定

<解説 >

従業者の教育・訓練は標準予防策と感染経路別予 防策の理解と実践を担保するために不可欠なもので ある。また，感染性微生物伝播に係る予防対策の原 則と実践についての教育・訓練及び助言は，業務開 始時または当該器具・器材を初めて使用する際に行 う必要がある。血液・体液曝露防止, 手指や環境の 污染を介した間接接触感染防止の目的から，感染制 御の専門家を通じて実効的な情報提供と教育・訓練 及び助言の機会を持ち，対応する必要がある9。医
療機器，医療材料の変更や導入に伴う手順の改訂時 には，最新の情報に基づいた教育・訓練及び助言が 必要である。従業者の職種, 使用者, 責任者等を対 象とし，時期・教育形態（情報伝達, 演習, シミュ レーション，時間）を考慮したうえで，個々に適し た教育・訓練及び助言を行うことは，感染対策の周 知及びその学習効果を向上させることができる。定 型的及び定期的な教育・研修とは異なるため，当該 状況が発生した際に実施することでよい。

\section{5. 多剂耐性菌の監視および対応}

項目 58. 多剂耐性菌が検出されている場合には，カ ルテで通知されるなど院内で情報共有ができる。

<カテゴリー>

年 1 回

$<$ 解説 >

救急外来には入院や高齢者施設入所歴のある患者 が受診することも多い。このような患者では多剤耐 性菌を保有している可能性を想定する必要がある。

入院までに救急外来で長時間待機が必要となる場合 も多く, 狭いスペースや多忙な医療従事者の影響を 受け，多剤耐性菌の患者間伝播や環境の污染が生じ やすい。接触予防策が必要となる多剂耐性菌 (MRSA, VRE, 多剂耐性緑膿菌, 多剂耐性アシネト バクター菌など）が検出されていることが事前にわ かっている患者ではカルテの表紙（電子カルテでは トップページ）などにその情報がわかりやすく表示 され，救急外来で患者を初めて診療する医療従事 者が速やかに認識できるようにすることが望まし ( 5)。なお，院内の複数の病棟で多剂耐性菌のアウ トブレイクが発生している場合には，救急外来が感 染拡大の場となっているリスクもある。このため, 院内の多剂耐性菌検出状況は救急外来と情報共有さ れることが望ましい 83$) 。$ 


\section{6. 新興・再興感染症対策}

項目 59. 新興・再興感染症患者に対する初期対応手 順が準備されている。

<カテゴリー＞

臨時

$<$ 解説 $>$

感染症法によって医師の届出を要する新型インフ ルエンザなど新興・再興感染症が流行する際には, 疑似症患者と確定患者は感染症指定医療機関に入院 勧告されることが想定される。一方，保健所を介し た行政検査（地方衛生研究所における病原体検査） を受ける前には，一般医療機関の救急外来に疑い患 者が受診することも想定しておく必要がある。主に 外国で流行している疾患が想定されるため，流行地 の滞在歴や潜伏期間などを基に厚生労働省から症例 定義が公表されることが多い。この症例定義を基 に，疑い患者が受診した場合の初期対応手順（待合 室，診察室，動線の確保などを含む）について，ア ルゴリズムなどを利用して，わかりやすくまとめて おくことが望ましい6,84)。最寄りの保健所など関係 機関の連絡先をまとめておくことも推奨される。ま た，保健所や感染症指定医療機関に相談し，行政検 査や転院（感染症指定医療機関への移送）を行う場 合の手順も想定しておくことが望ましい。

\section{7. 行政との連携}

項目 60. 感染症法により指定を受けている感染症の 報告手順，連絡先が周知されている。

<カテゴリー>

年 1 回

$<$ 解説 $>$

感染症法で医師の届出の必要な感染症は新感染 症， 1 類から 5 類感染症, 新型および再興型インフ ルエンザに分類されている（このほかに 2 年を目 安に指定される指定感染症がある)。新感染症, 1 類から 3 類感染症と 4 類および 5 類感染症の一部
（麻疹，風疹，髄膜炎菌感染症）は診断後直ちに最 寄りの保健所に届出することが求められている。 届出の必要な感染症について，わかりやすく整理 しておくとともに夜間休日も患者を診療すること が多い救急外来では，24 時間体制で保健所（都道 府県衛生部）に連絡を取ることができる体制を整 備しておくことが望ましい。患者を入院させる場 合には感染対策などについて相談ができるよう, 院內の感染制御の専門家にも必要時に連絡を取れ る体制を構築しておくことが推奨される ${ }^{6)}$ 。なお， 新型インフルエンザ発生時には流行状況に応じ て, 届出の有無が変わるため, 行政からの通知を 参照しながら，随時院内で周知を図る必要があ る。

$$
\text { 文献 }
$$

1) Kudo $D$, Sasaki J, Ikeda $H$, et al: A survey on infection control in emergency departments in Japan. Acute Med Surg. 2018; 5: 374-9.

2) 森田正則, 佐々木淳一, 佐藤格夫, 他: 病院前救護活動 における感染対策の現状と課題.日臨救急医会誌 (JJSEM). 2018; 21: 572-7.

3) 志馬伸朗，柳原克紀，渡邊学，他: 救急部門における微 生物検査に関する多施設調査. 日臨微生物会誌. 2019; 29: 28-31.

4) Cho SY, Kang JM, Ha YE, et al: MERS-CoV outbreak following a single patient exposure in an emergency room in South Korea: an epidemiological outbreak study. Lancet. 2016; 10048: 994-1001.

5) Liang SY, Theodoro DL, Schuur JD, et al: Infection prevention in the emergency department. Ann Emerg Med. 2014; 64 299-313.

6) World Health Organization (WHO): Hospital preparedness for epidemics. 2014.

7) Centers for Disease Control and Prevention (CDC): Guide to infection prevention for outpatient settings. 2015.

8) Trinh TT, Chan PA, Edwards O, et al: Peripheral venous catheter-related Staphylococcus aureus bacteremia. Infect Control Hosp Epidemiol. 2011; 32: 579-83.

9) Siegel JD, Rhinehart E, Jackson M, et al: 2007 Guideline for Isolation Precautions: Preventing Transmission of Infectious Agents in Health Care Settings. Am J Infect Control. 2007; 35: S65-164.

10) Labor USDo: RESPIRATOR FIT TESTING. https://www. osha.gov/video/respiratory_protection/fittesting_transcri pt.html 
11) 感染症の予防及び感染症の患者に対する医療に関する 法律 (平成十年法律第百十四号). 施行日: 平成二十八 年四月一日. https://elaws.e-gov.go.jp/search/elawsSearch/ elaws_search/lsg0500/detail?lawld=410AC0000000114

12）阿彦忠之，猪狩英俊，久保秀一，他：結核院内（施設 内）感染対策の手引き平成 26 年版. 平成 25 年度厚生 労働科学研究費補助金インフルエンザ等新興再興感染 症研究事業「結核の革新的な診断・治療及び対策の強 化に関する研究」. 2014.

13) Jensen PA, Lambert LA, lademarco MF, et al: Guidelines for preventing the transmission of Mycobacterium tuberculosis in health-care settings, 2005. MMWR Recomm Rep. 2005; 54: 1-141.

14) 岡部信彦, 荒川創一, 岩田敏, 他: 一般社団法人日本環 境感染学会 医療関係者のためのワクチンガイドライン 第 2 版（第 1 版: 院内感染対策としてのワクチンガイド ライン). 日環境感染会誌. 2014; 29: np1-S13.

15) 国公立大学附属病院感染対策協議会: 病院感染対策ガイ ドライン. 2018.

16) 厚生労働省: 特定接種 (医療分野). Available on line at: http://www.mhlw.go.jp/stf/seisakunitsuite/bunya/kenkou_ir you/kenkou/kekkaku-kansenshou/infulenza/tokuteisesshu.html

17) Gonçalves Bd, Lambert Passos SR, Borges Dos Santos MA, et al: Systematic review with meta-analyses and critical appraisal of clinical prediction rules for pulmonary tuberculosis in hospitals. Infect Control Hosp Epidemiol. 2015; 36: 204-13.

18) Bloch $A B$, Orenstein $W A$, Ewing $W M$, et al: Measles outbreak in a pediatric practice: airborne transmission in an office setting. Pediatrics. 1985; 75: 676-83.

19) Bonifait L, Charlebois R, Vimont A, et al: Detection and quantification of airborne norovirus during outbreaks in healthcare facilities. Clin Infect Dis. 2015; 61: 299-304.

20) Verani $M$, Bigazzi $R$, Carducci $A$ : Viral contamination of aerosol and surfaces through toilet use in health care and other settings. Am J Infect Control. 2014; 42: 758-62.

21) Chen YC, Huang LM, Chan $C C$, et al: SARS in hospital emergency room. Emerg Infect Dis. 2004; 10: 782-8.

22) Jefferson T, Del Mar CB, Dooley L, et al: Physical interventions to interrupt or reduce the spread of respiratory viruses. Cochrane Database Syst Rev. 2011; 7: Cd006207.

23) Radonovich LJ Jr, Simberkoff MS, Bessesen MT, et al: N95 Respirators vs Medical Masks for Preventing Influenza Among Health Care Personnel: A Randomized Clinical Trial. JAMA. 2019; 322: 824-33.

24) Gehanno JF, Pestel-Caron $M$, Nouvellon $M$, et al: Nosocomial pertussis in healthcare workers from a pediatric emergency unit in France. Infect Control Hosp Epidemiol. 1999; 20: 54952.

25) Otter JA, Donskey C, Yezli S, et al: Transmission of SARS and MERS coronaviruses and influenza virus in healthcare settings: the possible role of dry surface contamination. J Hosp Infect. 2016; 92: 235-50.

26) Fischer WA 2nd, Hynes NA, Perl TM: Protecting health care workers from Ebola: personal protective equipment is critical but is not enough. Ann Intern Med. 2014; 161: 753-4.

27) 東京都福祉保健局: 新型インフルエンザの発生に備え て. 2017. Available online at: http://www.fukushihoken. metro.tokyo.jp/iryo/kansen/shingatainflu/keihatsu.files/poly glot-pamphlet.pdf

28) 東京都福祉保健局: 医療機関受診のための多言語ガイド ブ http://www.fukushihoken.metro.tokyo.jp/iryo/kansen/ tagengoguide.files/tagengogaido2019-mihiraki.pdf

29) Srinivasan A, McDonald LC, Jernigan D, et al: Foundations of the severe acute respiratory syndrome preparedness and response plan for healthcare facilities. Infect Control Hosp Epidemiol. 2004; 25: 1020-5.

30) World Health Organization (WHO): Global Open consultation for innovative Personal Protective Equipment. 2017.

31) Hashikura M, Kizu J: Stockpile of personal protective equipment in hospital settings: preparedness for influenza pandemics. Am J Infect Control. 2009; 37: 703-7.

32) World Health Organization (WHO): Hospital preparedness checklist for pandemic influenza: focus on pandemic (H1N1) 2009. 2009.

33) Helm RE, Klausner JD, Klemperer JD, et al: Accepted but unacceptable: peripheral IV catheter failure. J Infus Nurs. 2015; 38: 189-203.

34) Pujol M, Hornero A, Saballs $M$, et al: Clinical epidemiology and outcomes of peripheral venous catheter-related bloodstream infections at a university-affiliated hospital. J Hosp Infect. 2007; 67: 22-29.

35) Centers for Disease Control and Prevention (CDC): Guideline for Isolation Precautions: Preventing Transmission of Infectious Agents in Healthcare Settings 2007. 2007.

36) Tran K, Cimon K, Severn $M$, et al: Aerosol-Generating Procedures and Risk of Transmission of Acute Respiratory Infections: A Systematic Review [Internet]. 2011. Available online at: http://www.cadth.ca/media/pdf/M0023__Aerosol_ Generating_Procedures_e.pdf

37) Krieger JN, Kaiser DL, Wenzel RP: Urinary tract etiology of bloodstream infections in hospitalized patients. J Infect Dis. 1983; 148: 57-62.

38) Haley RW, Culver DH, White JW, et al: The nationwide nosocomial infection rate. A new need for vital statistics. Am J Epidemiol. 1985; 121: 159-67.

39) Gould CV, Umscheid CA, Agarwal RK, et al: Guideline for prevention of catheter-associated urinary tract infections 2009. Infect Control Hosp Epidemiol. 2010; 31: 319-26.

40) Turck M, Goffe B, Petersdorf RG: The urethral catheter and urinary tract infection. J Urol. 1962; 88: 834-7. 
41) Ehrenkranz NJ, Alfonso BC: Failure of bland soap handwash to prevent hand transfer of patient bacteria to urethral catheters. Infect Control Hosp Epidemiol. 1991; 12: 654-62.

42) Tenke P, Kovacs B, Bjerklund Johansen TE, et al: European and Asian guidelines on management and prevention of catheter-associated urinary tract infections. Int J Antimicrob Agents. 2008; 31 Suppl 1: S68-78.

43) 職業感染制御研究会: エピネット日本版サーベイ 2011 結果概要報告「エピネット日本版B 皮膚粘膜曝露」. 2011.

44) Theodoro D, Olsen MA, Warren DK, et al: Emergency Department Central Line-associated Bloodstream Infections (CLABSI) Incidence in the Era of Prevention Practices. Acad Emerg Med. 2015; 22: 1048-55.

45) Siempos II, Kopterides P, Tsangaris I, et al: Impact of catheterrelated bloodstream infections on the mortality of critically ill patients: a meta-analysis. Crit Care Med. 2009; 37: 2283-9.

46) O'Grady NP, Alexander M, Burns LA, et al: Guidelines for the prevention of intravascular catheter-related infections. Am J Infect Control. 2011; 39: S1-34.

47) Berenholtz SM, Pronovost PJ, Lipsett PA, et al: Eliminating catheter-related bloodstream infections in the intensive care unit. Crit Care Med. 2004; 32: 2014-20.

48) 木村哲: 医療現場における職業感染予防と曝露後の対 処. 医薬ジャーナル社，大阪，2015，p96-100.

49) 国立国際医療研究センター 国際感染症対策室: 重症熱 性血小板減少症候群診療の手引き. 2016.

50) Heymann DL: Control of Communicable Diseases Manual, 20th Edition. APHA Press, 2014.

51) World Health Organization (WHO): Avian influenza A (H7N9) virus: post-exposure antiviral chemoprophylaxis of close contacts of a patient with confirmed H7N9 virus infection and/or high risk poultry/environmental exposures. 2014.

52) 国公立大学附属病院感染対策協議会: 病院感染対策ガイ ドライン 2018. じほう, 東京, 2018

53) Zachoval R, Frösner G, Deinhardt F, et al: Persistence of hepatitis $B$ virus antigens in dried blood. Lancet. 1981; 8223: 778.

54) Doultree JC, Druce JD, Birch CJ, et al: Inactivation of feline calicivirus, a Norwalk virus surrogate. J Hosp Infect. 1999; 41: 51-7.

55) Mbithi JN, Springthorpe VS, Sattar SA: Chemical disinfection of hepatitis $A$ virus on environmental surfaces. Appl Environ Microbiol. 1990; 56: 3601-4.

56) Centers for Disease Control and Prevention (CDC): Updated norovirus outbreak management and disease prevention guidelines. 2011.

57) 一般社団法人 アルコール協会：ノロウイルスに係るエ タノール使用ガイドライン. 2015. Available online at: http://www.alcohol.jp/download/noroguideline1.pdf

58) 社団法人日本感染症学会, 社団法人日本化学療法学会, 日本環境感染学会, 他: 微量採血用穿刺器具の取り扱い について. 2008
59) 消化器内視鏡の感染制御に関するマルチソサエティ実践 ガイド作成委員会（日本環境感染学会，日本消化器内視 鏡学会，日本消化器内視鏡技師会）：消化器內視鏡の感 染制御に関するマルチソサエティ実践ガイド［改訂 版]. 2013.

60) IDWR: 〈注目すべき感染症〉RS ウイルス感染症. 2017. Available online at: https://www.niid.go.jp/niid/ja/rs-virus$\mathrm{m} / \mathrm{rs}$-virus-idwrc/7509-idwrc-1734.html

61) 厚生労働省検疫所: 中東呼吸器症候群コロナウイルス （MERS-CoV）の発生報告. 2017. Available online at: http://www.forth.go.jp/topics/2017/06141127.html

62 ) 厚生労働省: 重症熱性血小板減少症候群（SFTS）に関す る Q\&A. 2017. Available online at: http://www.mhlw.go. jp/bunya/kenkou/kekkaku-kansenshou19/sfts_qa.html

63) 消防庁救急企画室長: 救急隊の感染防止対策の推進につ いて（通知）救急隊の感染防止対策マニュアル（Ver. 1.0). 消防救第 49 号平成 31 年 3 月 28 日.

64) 青木正和: 日常診療・業務に役立つ結核病学 結核症の 診断 発病の診断. 日胸臨. 2000; 59: 944-59.

65) 安田康晴: 感染防止対策と個人防護. へるす出版, 東京, 2014, p44.

66) 厚生労働省：感染症法に基づく医師の届出のお願い. Available online at: http://www.mhlw.go.jp/stf/seisakunitsuite/ bunya/kenkou_iryou/kenkou/kekkaku-kansenshou/kekkakukan senshou11/01.html

67) 国立感染症研究所感染症疫学センター, 国立国際医療研 究センター病院国際感染症センター: 中東呼吸器症候群 （MERS）・鳥インフルエンザ（H7N9）患者搬送における 感染対策. 2014. Available online at: https://www.niid. go.jp/niid/ja/flu-m/flutoppage/2273-

flu2013h7n9/idsc/4859- patient-transportmersandh7n9.html

68) 山中喜代治: 新結核菌検査指針と一般病院での抗酸菌検 査. 結核. 2002; 77: 99.

69) 厚生労働省検疫所: FORTH 海外で健康に過ごすために. Available online at: http://www.forth.go.jp/moreinfo/topics/ index.html

70) 厚生労働省健康局結核感染症課: 新型インフルエンザ対 策（特措法を含め）. 2014. Available online at: https://www. niid.go.jp/niid/images/idsc/kikikanri/H26/20141015-03.pdf \#search='新型インフルエンザ等対策特別措置法'

71) 感染症の予防及び感染症の患者に対する医療に関する 法律. Available online at: https://elaws.e-gov.go.jp/search/ elawsSearch/elaws_search/lsg0500/detail?lawld=410AC0000 000114\&openerCode $=1 \# \mathrm{H}$

72) The Australasian College for Emergency Medicine (ACEM): EMERGENCY DEPARTMENT DESIGN GUIDELINES. 2014.

73) Centers for Disease Control and Prevention (CDC): Guidelines for Environmental Infection Control in Health-Care Facilities. 2003. 
74) Centers for Disease Control and Prevention (CDC): Guidelines for preventing the transmission of Mycobacterium tuberculosis in health-care facilities. 2005.

75) Centers for Disease Control and Prevention (CDC): Notice to Readers Update: management of patients with suspected viral hemorrhagic fever--United States. 1995.

76) Martinez JA, Ruthazer R, Hansjosten $K$, et al: Role of environmental contamination as a risk factor for acquisition of vancomycin-resistant enterococci in patients treated in a medical intensive care unit. Arch Intern Med. 2003; 163: 1905-12.

77) Donskey CJ: The role of the intestinal tract as a reservoir and source for transmission of nosocomial pathogens. Clin Infect Dis. 2004; 39: 219-26.

78) Dassut B: The implementation of a commode cleaning and identification system. Nurs Times. 2004; 100: 47.

79) Dick EC, Jennings LC, Mink KA, et al: Aerosol transmission of rhinovirus colds. J Infect Dis. 1987; 156: 442-8.

80) Tang JW, Nicolle A, Pantelic J, et al: Different types of dooropening motions as contributing factors to containment failures in hospital isolation rooms. PLoS One. 2013; 8: e66663.

81) Kalliomäki $P$, Saarinen $P$, Tang JW, et al: Airflow patterns through single hinged and sliding doors in hospital isolation rooms - Effect of ventilation, flow differential and passage. Building and Environment. 2016; 107: 154-68.

82) 東京都福祉保健局: 結核患者収容モデル事業実施要領. 2007. Available online at: http://www.fukushihoken.metro. tokyo.jp/iryo/kansen/kekkaku/model.files/model_yoryo.pdf

83) 前崎繁文: 救急で問題となる薬剂耐性菌 MRSA から MDRP まで. 日救急医会誌. 2010; 21: 51-62.

84) 加藤康幸, 西條政幸, 足立拓也，他：ウイルス性出血熱 一診療の手引き—2017 改訂新版. 2017.

$$
\text { 項目一覧 }
$$

\section{1. 管理体制}

\section{(1) 組織}

項目 1. 院内の感染対策委員会に救急外来の責任者が含まれ ている。

項目 2. 新型インフルエンザなど新興・再興感染症流行時な どに設置される対策本部に，救急外来の責任者が含まれて いる。

項目 3. 感染制御の専門家に必要時 24 時間相談できる体制 を整えている。

項目 4 . 救急外来専用の感染対策マニュアルが整備されてい る，あるいは感染対策マニュアルに救急外来に関する事項 が含まれ，定期的に見直し，改訂が行われている。

\section{(2) 教育・検診・予防接種体制}

\section{1) 感染制御に関する管理・教育}

項目 5. 常勤職員だけでなく，救急外来に関わる職員全員に 対し，感染制御に関する研修を行っている。

項目 6. N95 マスクの正しい着脱のトレーニングと，定期的 なフィットテストが実施されている。

項目 7. 新型インフルエンザなど新興・再興感染症流行時に は，症例定義，感染制御法などに関する情報が速やかに周 知される。

\section{(2) 結核検診}

項目 8. 入職時及び最低年 1 回の結核に係る定期の健康診断 が実施されている。

\section{(3) ワクチン接種}

項目 9. インフルエンザワクチンの接種が推奨され，管理さ れている。

項目 10. 麻疹，水痘，風疹，ムンプス，HBV の免疫（ワクチ ン接種回数，抗体価）が確認され管理されている。

項目 11. 新型インフルエンザなど新興・再興感染症流行時に は，行政機関と連携して臨時の予防接種ができる体制があ る。

\section{2. 感染が疑われる患者への対応}

\section{(1) 院内}

\section{(1) 早期認知，初期対応}

項目 12. 患者から事前の電話連絡があった場合，あるいは受 付において，患者に最初に接触する職員が感染症を認知す る為に聴取する質問項目をチェックリスト形式で作成し, 適宜アップデートしている。

項目 13. 電話連絡の場合，患者を適切な入口入誘導できる説 明体制があり，感染症が疑われる受診患者を適切な入口へ 誘導する見やすい掲示がある。

項目 14. 患者の対応にあたる場合は，救急外来の受付職員を 含め, 救急外来職員はサージカルマスク着用を原則とす る。

項目 15. 受付事務員を含む救急外来スタッフがトリアージを するための問診票あるいは質問票（渡航先及び滞在期間， 感染症曝露の可能性の有無を含む）を日本語と外国語（英 語のほか，感染症流行地で使用される言語を含むことが望 ましい）で用意している。

項目 16. 感染スクリーニング体制が敷かれている。

項目 17. 新型インフルエンザなど新興・再興感染症流行時に は，疑い例を含む症例定義に基づく感染スクリーニング体 制が強化される。

項目 18. 陰圧，HEPA フィルターなどが備えられている特殊 または専用診察室への患者および医療従事者の動線が周知 され実施されている。

項目 19. 主な症状別（発熱・発疹，消化器症状，呼吸器症 
状）に基本的な動線，隔離方法，対応がマニュアル化さ れ，感染症が疑われる患者の動線とその他の患者および職 員の動線が適切に設定されている。

\section{(2) 感染予防の具体策}

項目 20. 標準予防策に必要な個人防護具（PPE）は，各種サ イズを十分量かつ必要なときにすぐ使えるように整ってい る。

項目 21. 外傷, 嘔吐など症状に応じて, 感染制御に必要な物 品をすぐに使用できるよう準備している。

項目 22. 末梢静脈ラインを確保する場合にも，院内のマニュ アルに沿って清潔操作を行っている。

項目 23. 感染が疑われない場合であっても，気管挿管を行う 際には，標準予防策（手袋，アイガード，サージカルマス ク等）が実施されている。

項目 24. 入院が決定した患者に対し，尿道カテーテルをルー チンに挿入していない。

項目 25. 尿道カテーテル挿入は無菌操作で行われている。 項目 26. 血液体液曝露の危険がある患者の診察や胸腔ドレ ナージ，腰椎穿刺等施行時にはアイガード，サージカルマ スクを使用している。

項目 27. 中心静脈カテーテル挿入は適応を慎重に吟味し，実 施する場合には CLABSI prevention bundle を遵守している。

項目 28. 中心静脈カテーテルを挿入する場合には，手技を 行っている以外の医療従事者により清潔操作維持を監視 し，違反があった場合には手技を中止している。

項目 29. 感染につながる曝露が疑われる場合の対処手順が整 備されている。

\section{(3) 環境整備}

項目 30. 使用後診察室の清掃, 高頻度接触面や污染箇所の環 境整備 (湿式), アルコール抵抗性の微生物に対する適切 な薬剂と濃度に関する手順が周知徹底されている。

項目 31. 再利用可能な機器（超音波, 血糖測定などのポイン トオブケア物品，内視鏡など）は次の患者に使用される前 に適切に洗浄・消毒・滅菌されている。

項目 32. 再利用可能な機器を洗浄・消毒・滅菌する場合には 適切に個人防護具（PPE）を使用している。

項目 33. 再利用（洗浄・消毒・滅菌）の手順を Hands-on で 教育している。

\section{(2) 院外}

\section{(4) 救急搬送}

項目 34. 病院前救護活動を行う職員からの情報に基づき，病 院前救護活動を行う職員に対し適切な感染防止対策を指示 している，あるいはすることができる。

項目 35. 当該感染症について, 病院前救護活動を行う職員に 対して行う感染防止対策の指示内容が用意されている。

項目 36. 病院前救護活動を行う職員が，結核，麻疹，水痘な どが確定もしくは強く疑われる情報を得た場合は，病院前
救護活動を行う職員に対し適切な感染防止対策を指示して いる。

項目 37. 診断に基づき，病院前救護活動を行う職員に対し職 業感染対策，表面消毒，環境回復について助言を行ってい る。

項目 38. 診断に基づき, 病院前救護活動を行う職員に対し職 業感染対策，表面消毒，環境回復についての助言内容が用 意されている。

項目 39. 結核，麻疹，水痘などが確定もしくは強く疑われる 場合は，診断に基づき，病院前救護活動を行う職員に対し 職業感染対策，適切な清掃，表面清拭・消毒，環境回復な どについて助言を行っている。

\section{(5) 病院間搬送}

項目 40. 必要に応じ患者の個人情報に配慮した上で，前医に 感染対策について適切な助言を行っている。

項目 41. 前医の情報から，適切な搬送時期，搬送方法につい て指示を行っている。

項目 42. 病院から外部へ患者搬送を行う場合には，受け入れ 施設や搬送車両に対して感染制御に関する情報を適切に提 供し指導している。

3. モニタリング

\section{(1) 機器，環境など}

項目 43. 特殊診察室を設置し陰圧室の陰圧（差圧）, フィル ター管理を定期的に確認する体制がある。

\section{4. 構造，ハードウェアの感染リスクの管理}

\section{(1) トイレ}

項目 44. 救急外来内に複数のトイレがある。

項目 45. 個室（隔離用診療室）内，あるいは近接した場所に トイレがある。

項目 46. トイレに手洗い設備が備えられている。 項目 47. トイレの床は清掃しやすい構造である。

\section{(2) 待合室}

項目 48. 感染症の流行期，あるいは必要時には，待合室，診 察室をコホートしている。

項目 49. 受付にサージカルマスク, 手指消毒薬，ティシュ ペーパーが常備されており，足踏み式のゴミ箱へただち に，適切に廃棄できるよう運用されている。

項目 50. 建物外にインターホン，電話等，院内の職員が応答 できる設備がある。

項目 51. 患者待合室に手指衛生を行うことができる設備があ る。

項目 52. イスは湿式清掃可能な素材である。

項目 53. 待合室の近くにトイレがあり，動線が明確にされて いる。 


\section{(3) 診察区域}

項目 54. 特殊診察室には個人防護具（PPE）などを備えた前 室がある。

項目 55. 診察室，前室のドアは引き戸になっている。

項目 56. 行政機関に提出が必要な検体，および採取時の感染 制御法について周知されている。

\section{(4) 新規に採用される医療機器・医療材料}

項目 57. 新規の医療機器, 医療材料が導入される際には, 感 染制御の専門家の確認が行われ, 現場に対し適切な助言が
行なわれている。

\section{5. 多剂耐性菌の監視および対応}

項目 58. 多剂耐性菌が検出されている場合には, カルテで通 知されるなど院内で情報共有ができる。

\section{6. 新興・再興感染症対策}

項目 59. 新興・再興感染症患者に対する初期対応手順が準備 されている。

\section{7. 行政との連携}

\section{略語一覧}

\begin{tabular}{|c|c|c|}
\hline AIDS & Acquired Immune Deficiency Syndrome & 後天性免疫不全症候群 \\
\hline BCG & Bacille de Calmette et Guérin & カルメット・ゲラン桿菌 \\
\hline BCP & Business Continuity Plan & 事業継続計画 \\
\hline CDC & Centers for Disease Control and Prevention & アメリカ疾病管理予防センター \\
\hline CLABSI & Central Line-Associated Blood Stream Infection & 中心ライン関連血流感染 \\
\hline CRBSI & Catheter-Related Blood Stream Infection & カテーテル関連血流感染 \\
\hline FORTH & FOR Traveler's Health & 厚生労働省検疫所 \\
\hline HB & Hepatitis B & B 型肝炎 \\
\hline HBIG & Hepatitis B Immune Globulin & B 型肝炎免疫グロブリン \\
\hline HBs & Hepatitis B Virus Surface & B 型肝炎ウイルス表面 \\
\hline HBV & Hepatitis B Virus & B 型肝炎ウイルス \\
\hline HCV-RNA & Hepatitis C Virus - Ribonucleic Acid & C 型肝炎ウイルスーリボ核酸 \\
\hline HEPA & High Efficiency Particulate Air & 高性能粒子捕捉器 \\
\hline HIV & Human Immunodeficiency Virus & ヒト免疫不全ウイルス \\
\hline ICT & Infection Control Team & 感染対策チーム \\
\hline IGRA & Interferon-Gamma Release Assays & インターフェロン $-\gamma$ 遊離試験 \\
\hline MERS & Middle East Respiratory Syndrome & 中東呼吸器症候群 \\
\hline MRSA & Methicillin-Resistant Staphylococcus aureus & メチシリン耐性黄色ブドウ球菌 \\
\hline MSBP & Maximal Sterile Barrier Precautions & マキシマルバリアプリコーション \\
\hline PPE & Personal Protective Equipment & 個人（用）防護具 \\
\hline RSV & Respiratory Syncytial Virus & RS ウイルス \\
\hline SARS & Severe Acute Respiratory Syndrome & 重症急性呼吸器症候群 \\
\hline SFTS & Severe Fever with Thrombocytopenia Syndrome & 重症熱性血小板減少症候群 \\
\hline VRE & Vancomycin-Resistant Enterococci & バンコマイシン耐性腸球菌 \\
\hline
\end{tabular}


項目 60. 感染症法により指定を受けている感染症の報告手 順，連絡先が周知されている。 
環境感染誌

Vol. 35 no. 3, 2020

救急外来部門における感染対策検討委員会および

合同ワーキンググループ 委員一覧

\section{委員長}

佐々木淳一 慶應義塾大学医学部救急医学

\section{作成委員}

椎野 泰和

加藤 康幸 国際医療福祉大学医学部感染症学

工藤 大介東北大学大学院医学系研究科外科病態学講 座救急医学分野

藤田昌久日本医科大学付属病院医療安全管理部感染 制御室

宮入烈国立成育医療研究センター生体防御系内科 部感染症科

望月 徹 日本医科大学武蔵小杉病院感染制御部/救命 救急科（救命救急センター）

奥田拓史東北大学大学院医学系研究科総合医療学分 野

長門直 公立学校共済組合中国中央病院内科

鍋谷佳子 大阪大学医学部附属病院看護部
委員

池田 弘人 帝京大学医学部救急医学

志馬 伸朗 広島大学大学院救急集中治療医学

佐藤 格夫 愛媛大学大学院医学系研究科救急医学

松山 重成兵庫県災害医療センター高度救命救急セン ター

横田裕行日本医科大学大学院医学研究科救急医学分 野

大毛 宏喜 広島大学病院感染症科

渡邊 学 東邦大学医療センタ一大橋病院外科

森田 正則 堺市立総合医療センター救命救急センター

添田博東京医科大学病院薬剤部

柳原 克紀 長崎大学大学院病態解析・診断学（臨床検 查医学)

協力者（日本結核・非結核性抗酸菌症学会）

藤田 明 東京都保健医療公社多摩南部地域病院

担当理事 (日本救急医学会)

高橋 毅 国立病院機構熊本医療センター

代表理事（日本救急医学会）

嶋津 岳士 大阪大学大学院医学系研究科 


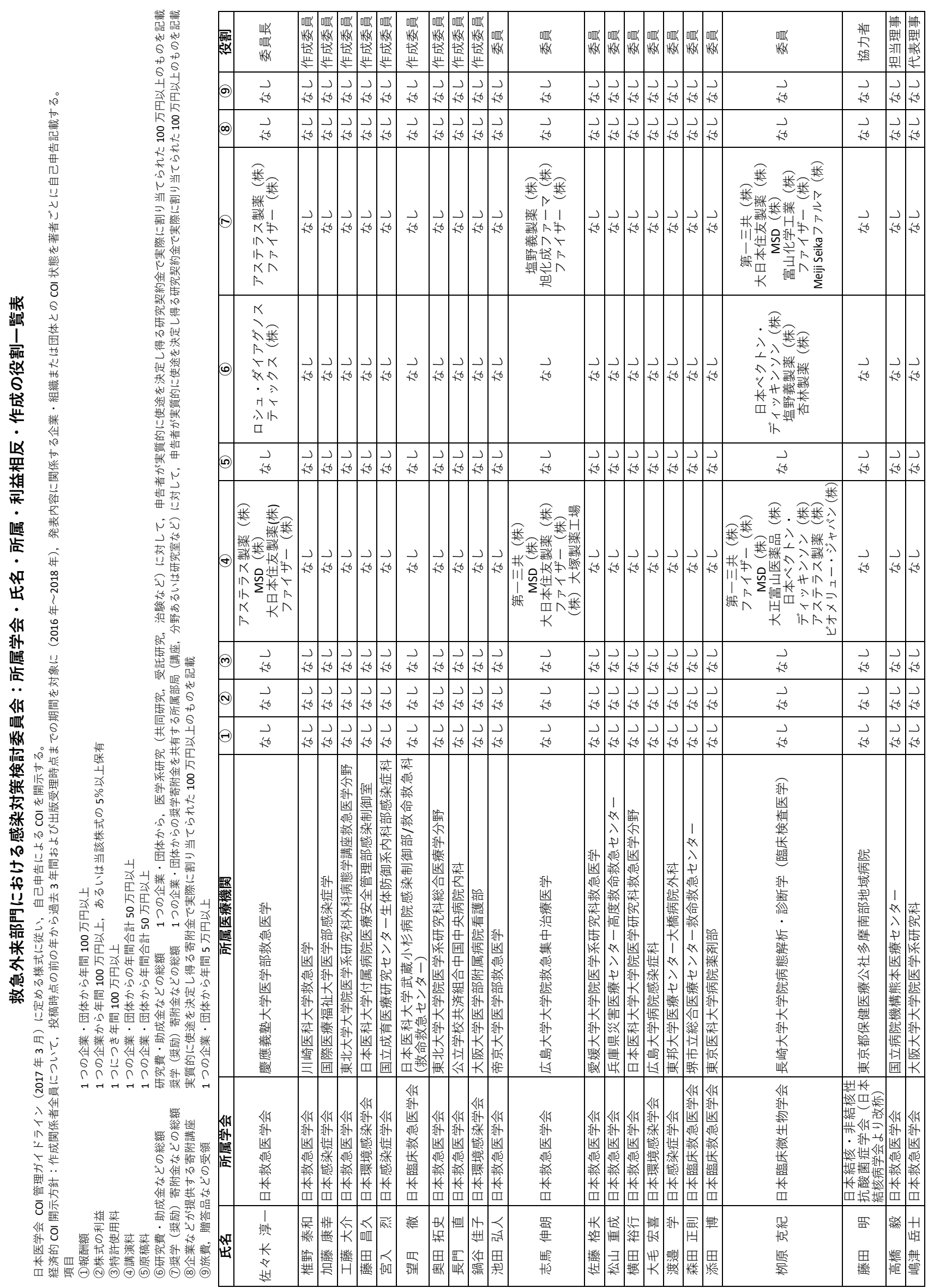

